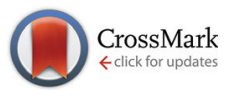

Cite this: Dalton Trans., 2016, 45, 2208

Received 31st August 2015, Accepted 3rd November 2015 DOI: $10.1039 / \mathrm{c} 5 \mathrm{dt} 03374 \mathrm{~h}$ www.rsc.org/dalton

\section{Hydrophosphination reactions with transition metal ferrocenylphosphine complexes $\dagger$}

\author{
Julian Rodger Frederic Pritzwald-Stegmann, Peter Lönnecke and \\ Evamarie Hey-Hawkins*
}

\section{Introduction}

The majority of organometallic phosphine complexes involve mono-, bi- or polydentate tertiary phosphines, ${ }^{1}$ while primary and secondary phosphines have received much less attention, due to their toxicity and high reactivity (some are even pyrophoric). However, these phosphines are very interesting, as they facilitate post-coordination modification of the $\mathrm{P}-\mathrm{H}$ bond, allowing for chemical flexibility in the synthesis of new and intriguing transition metal phosphine complexes. ${ }^{2,3}$ Several air-stable primary and secondary phosphines have been reported; $;^{4-10}$ developments in this area include the use of bulky aryl groups ${ }^{7,8}$ or aminoalkyl substituents. ${ }^{9}$ A recent review by Higham et al. gives an excellent overview on primary phosphine chemistry, including air-stable phosphines. ${ }^{3}$

Due to the redox properties of the ferrocenyl unit and the possibility to readily obtain chiral compounds, ${ }^{11}$ ferrocenylphosphines are an important class of ligands in transition metal chemistry. ${ }^{11,12}$ Henderson et $a .^{4-6}$ used the methylferrocenyl fragment to stabilise primary phosphines. $\mathrm{FcCH}_{2} \mathrm{PH}_{2}\left[\mathrm{Fc}=\mathrm{Fe}\left(\eta^{5}-\mathrm{C}_{5} \mathrm{H}_{4}\right)\left(\eta^{5}-\mathrm{C}_{5} \mathrm{H}_{5}\right)\right]$ proved to be indefinitely air-stable, ${ }^{6}$ probably due to electronic rather than steric effects,

Institute of Inorganic Chemistry, Faculty of Chemistry and Mineralogy, Universität Leipzig, Johannisallee 29, 04103 Leipzig, Germany.E-mail: hey@uni-leipzig.de $\dagger$ Electronic supplementary information (ESI) available: Experimental and simulated ${ }^{1} \mathrm{H}$ and ${ }^{31} \mathrm{P}$ NMR spectra of $\mathbf{2 a}$ and $\mathbf{3 a}$ (only $\mathrm{PH}_{2}$ region); summary of data collection, structure solution and refinement details for 1a,c, 2a-c, 3a,b and 4a. CCDC 1420127-1420134. For ESI and crystallographic data in CIF or other electronic format see DOI: $10.1039 / \mathrm{c} 5 \mathrm{dt} 03374 \mathrm{~h}$ as well as having the ability to coordinate to molybdenum carbonyls or $\left[\left\{\mathrm{RuCl}_{2}(p \text {-cymene })\right\}_{2}\right]\left(p\right.$-cymene $\left.=1-\mathrm{Me}-4-i \mathrm{PrC}_{6} \mathrm{H}_{4}\right)$ without alteration of the $\mathrm{PH}_{2}$ group, whereas $\mathrm{P}-\mathrm{H}$ activation occurred in the reaction with $\left[\mathrm{Ru}_{3}(\mathrm{CO})_{12}\right]$ to give two products with capping phosphinidene ligands. ${ }^{5}$ Ferrocenylphosphine, $\mathrm{FcPH}_{2}$, was first published by Roesky et al. in 1989 as an airsensitive yellow oil prepared by reduction of $\mathrm{FcPCl}_{2}$ with $\mathrm{LiAlH}_{4}{ }^{13}$ Henderson et al. have obtained $\mathrm{FcPH}_{2}$ from the reduction of $\mathrm{FcP}(\mathrm{O})(\mathrm{OEt})_{2}$ with a mixture of $\mathrm{LiAlH}_{4}$ and $\mathrm{Me}_{3} \mathrm{SiCl}$ as a brown oil that crystallises upon standing. ${ }^{4}$ They reported that a solution of $\mathrm{FcPH}_{2}$ is slowly oxidised in $5 \mathrm{~d}$ to the corresponding primary phosphine oxide and phosphinic acid. ${ }^{4}$ We have previously extended this chemistry to the sterically demanding air-stable secondary and tertiary ferrocenylphosphines $\mathrm{PH}\left(\mathrm{CH}_{2} \mathrm{Fc}\right)_{2}$ and $\mathrm{P}\left(\mathrm{CH}_{2} \mathrm{Fc}\right)_{3}{ }^{14}$ and transition metal complexes thereof. ${ }^{14,15-19}$

$\mathrm{FcPH}_{2}$ is a remarkably convenient starting material considering its easy synthesis and stability compared with related compounds, but has mostly been neglected. In contrast, the highly reactive $\mathrm{PhPH}_{2}$ has been used extensively. ${ }^{20}$ We have previously reported the synthesis of $\left[\mathrm{MI}_{2}(\mathrm{CO})_{3}\left(\mathrm{PH}_{2} \mathrm{Fc}\right)_{2}\right](\mathrm{M}=$ $\mathrm{Mo}, \mathrm{W}){ }^{19}\left[\mathrm{Cp}^{*} \mathrm{TaCl}_{4}\left(\mathrm{PH}_{2} \mathrm{Fc}\right)\right]^{15}\left(\mathrm{Cp}^{*}=\mathrm{C}_{5} \mathrm{Me}_{5}\right)$ and $\left[\mathrm{RuCl}_{2}(p-\right.$ cymene) $\left.\left(\mathrm{PH}_{2} \mathrm{Fc}\right)\right]{ }^{17}$ Presented below is the synthesis and characterisation of the ferrocenylphosphine transition metal carbonyl complexes $\left[\mathrm{M}(\mathrm{CO})_{5}\left(\mathrm{PH}_{2} \mathrm{Fc}\right)\right](\mathbf{1 a}, \mathrm{M}=\mathrm{Cr} ; \mathbf{1} \mathbf{b}, \mathbf{M}=\mathbf{M o}$; 1c, $\mathrm{M}=\mathrm{W})$, cis-[M(CO) $\left.{ }_{4}\left(\mathrm{PH}_{2} \mathrm{Fc}\right)_{2}\right](2 \mathbf{a}, \mathrm{M}=\mathrm{Cr} ; 2 \mathbf{b}, \mathrm{M}=\mathrm{Mo} ; \mathbf{2 c}$, $\mathrm{M}=\mathrm{W})$ and $f a c-\left[\mathrm{M}(\mathrm{CO})_{3}\left(\mathrm{PH}_{2} \mathrm{Fc}\right)_{3}\right](\mathbf{3 a}, \mathbf{M}=\mathrm{Cr} ; \mathbf{3 b}, \mathbf{M}=\mathrm{Mo} ; \mathbf{3}$, $\mathrm{M}=\mathrm{W}$ ). Furthermore, the reactivity of the $\mathrm{P}-\mathrm{H}$ bond of the coordinated and free ligand in the hydrophosphination of alkenes was investigated, and the hydrophosphination 
products $\left[\mathrm{W}(\mathrm{CO})_{5}\left\{\mathrm{PH}(\mathrm{Fc})\left(\mathrm{CH}_{2} \mathrm{CH}_{2} \mathrm{CN}\right)\right\}\right](4 \mathrm{a}),\left[\mathrm{W}(\mathrm{CO})_{5}\{\mathrm{PH}(\mathrm{Fc})-\right.$ $\left.\left.\left(\mathrm{CH}_{2} \mathrm{CH}_{2} \mathrm{C}(\mathrm{O}) \mathrm{OMe}\right)\right\}\right]$ (4b) and $\mathrm{FcP}\left(\mathrm{CH}_{2} \mathrm{CH}_{2} \mathrm{CN}\right)_{2}$ (5) were obtained.

\section{Results and discussion}

\section{Synthesis}

Freshly prepared $\left[\mathrm{M}(\mathrm{CO})_{5}(\mathrm{thf})\right](\mathrm{M}=\mathrm{Cr}, \mathrm{Mo}, \mathrm{W})^{21}$ was added to a solution of $\mathrm{FcPH}_{2}{ }^{3}$ in THF at room temperature and the mixture was stirred for $30 \mathrm{~min}$ (Scheme 1). All volatile materials including unconsumed $\mathrm{M}(\mathrm{CO})_{6}$ and $\mathrm{FcPH}_{2}$ were removed under high vacuum $\left(10^{-3} \mathrm{mbar}\right)$ at elevated temperature to leave a pale orange powder of crude $\left[\mathrm{M}(\mathrm{CO})_{5}\left(\mathrm{PH}_{2} \mathrm{Fc}\right)\right]$ $(\mathbf{1 a}, \mathrm{M}=\mathrm{Cr} ; \mathbf{1 b}, \mathrm{M}=\mathrm{Mo} ; \mathbf{1} \mathbf{c}, \mathrm{M}=\mathrm{W})$, which was purified by column chromatography. Small amounts of cis-[M $\left.(\mathrm{CO})_{4}\left(\mathrm{PH}_{2} \mathrm{Fc}\right)_{2}\right](2 \mathbf{a}, \mathrm{M}=\mathrm{Cr} ; \mathbf{2 b}, \mathrm{M}=\mathrm{Mo} ; \mathbf{2} \mathbf{c}, \mathrm{M}=\mathrm{W})$ were also obtained by this method, since cis-[M(CO) $\left.{ }_{4}(\mathrm{thf})_{2}\right]$ is a side product in the preparation of $\left[\mathrm{M}(\mathrm{CO})_{5}(\mathrm{thf})\right] .^{21}$ The three complexes 1a-c are air- and moisture-stable and highly soluble in common organic solvents.

The bis-ferrocenylphosphine complexes cis- $\left[\mathrm{M}(\mathrm{CO})_{4}\left(\mathrm{PH}_{2} \mathrm{Fc}\right)_{2}\right]$ (2a, $\mathrm{M}=\mathrm{Cr} ; \mathbf{2} \mathbf{b}, \mathrm{M}=\mathrm{Mo}$ ) were obtained from two equivalents of $\mathrm{FcPH}_{2}$ and $\left[\mathrm{M}(\mathrm{CO})_{4}(\mathrm{nbd})\right]^{22}(\mathrm{M}=\mathrm{Cr}, \mathrm{Mo}$, nbd $=$ norbornadiene) in toluene after stirring at room temperature for $24 \mathrm{~h}$ (Scheme 2). In the case of cis-[W(CO) $\left.)_{4}\left(\mathrm{PH}_{2} \mathrm{Fc}\right)_{2}\right](2 \mathrm{c})$, a mixture of $\mathrm{FcPH}_{2}$ and cis-[W(CO) $\left.{ }_{4}(\mathrm{tmpa})\right]^{22}$ (tmpa $=N, N, N^{\prime}, N^{\prime}$-tetramethyl-1,3-propanediamine) in toluene was heated to $60{ }^{\circ} \mathrm{C}$ for $1 \mathrm{~d}$. Complexes $2 \mathbf{a}-\mathbf{c}$ crystallise from dichloromethane/ $n$-hexane as pale orange powders.

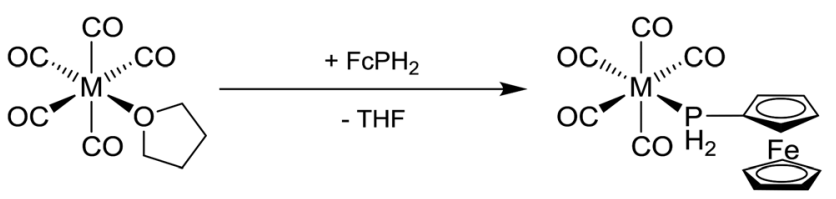

1a, $\mathrm{M}=\mathrm{Cr}$

1b, $M=M o$

1c, $M=W$

Scheme 1 Synthesis of $\left[M(C O)_{5}\left(\mathrm{PH}_{2} \mathrm{Fc}\right)\right](1 \mathrm{a}, \mathrm{M}=\mathrm{Cr} ; 1 \mathrm{~b}, \mathrm{M}=\mathrm{Mo} ; 1 \mathrm{c}$, $M=W)$.

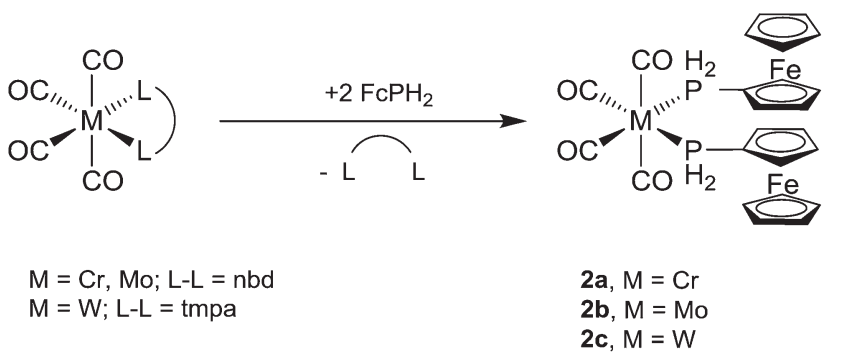

Scheme 2 Synthesis of cis- $\left[\mathrm{M}(\mathrm{CO})_{4}\left(\mathrm{PH}_{2} \mathrm{Fc}\right)_{2}\right](2 \mathrm{a}, \mathrm{M}=\mathrm{Cr} ; 2 \mathrm{~b}, \mathrm{M}=\mathrm{Mo}$; 2c, $M=W$ ).

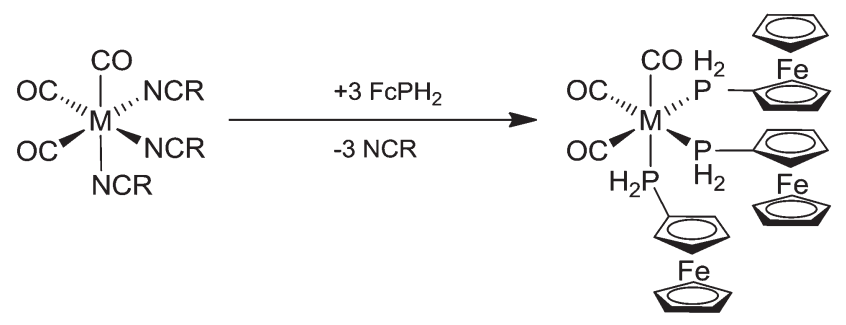

$\mathrm{M}=\mathrm{Cr}, \mathrm{Mo} ; \mathrm{R}=\mathrm{Me}$

$\mathrm{M}=\mathrm{W} ; \mathrm{R}=\mathrm{Et}$

3a, $\mathrm{M}=\mathrm{Cr}$

3b, $M=M o$

$3 c, M=W$

Scheme 3 Synthesis of fac- $\left[\mathrm{M}(\mathrm{CO})_{3}\left(\mathrm{PH}_{2} \mathrm{Fc}\right)_{3}\right](3 a, M=\mathrm{Cr} ; 3 \mathrm{~b}, \mathrm{M}=\mathrm{Mo}$; 3c, $M=W$ ).

The tris-ferrocenylphosphine complexes $f a c-\left[\mathrm{M}(\mathrm{CO})_{3}\left(\mathrm{PH}_{2} \mathrm{Fc}\right)_{3}\right]$ (3a, $\mathrm{M}=\mathrm{Cr} ; \mathbf{3 b}, \mathrm{M}=\mathrm{Mo} ; \mathbf{3 c}, \mathrm{M}=\mathrm{W}$ ) were obtained from three equivalents of $\mathrm{FcPH}_{2}$ and $f a c$ - $\left[\mathrm{M}(\mathrm{CO})_{3}(\mathrm{NCR})_{3}\right](\mathrm{M}=\mathrm{Cr}, \mathrm{Mo}, \mathrm{R}=$ $\mathrm{Me} ; \mathrm{M}=\mathrm{W}, \mathrm{R}=\mathrm{Et})^{21}$ in dichloromethane overnight at room temperature (Scheme 3). The air- and moisture-stable products were purified by column chromatography.

\section{Spectroscopic data}

The ${ }^{31} \mathrm{P}\left\{{ }^{1} \mathrm{H}\right\}$ NMR spectra show a remarkable difference between the three complexes with $\delta\left({ }^{31} \mathrm{P}\right)$ observed at progressively lower ppm in the order $\mathrm{Cr}>\mathrm{Mo}>\mathrm{W}(\mathbf{1 a}:-47.6, \mathbf{1 b}:-81.5$ and 1c: $-101.8 \mathrm{ppm})$. In the proton-coupled ${ }^{31} \mathrm{P}$ NMR spectra these singlets split into triplets $\left[{ }^{1} J_{\mathrm{PH}} \approx 334 \mathrm{~Hz}\right.$ (Table 1)]. In addition, the spectrum of $1 \mathrm{c}$ shows ${ }^{31} \mathrm{P}-{ }^{183} \mathrm{~W}$ coupling of $221 \mathrm{~Hz}$.

In the ${ }^{1} \mathrm{H}$ NMR spectra, the signals of the hydrogen atoms of the primary phosphine are shifted downfield from $3.81 \mathrm{ppm}$ in $\mathrm{FcPH}_{2}$ to $5.27 \mathrm{ppm}$ in $\mathbf{1 a}, 5.31 \mathrm{ppm}$ in $\mathbf{1 b}$ and $5.65 \mathrm{ppm}$ in $1 \mathrm{c}\left({ }^{1} \mathrm{~J}_{\mathrm{HP}}\right.$ increases from $203.6 \mathrm{~Hz}$ in $\mathrm{FcPH}_{2}$ to $333.9 \mathrm{~Hz}$ in $\mathbf{1 a}, 328 \mathrm{~Hz}$ in $\mathbf{1 b}$ and $341.5 \mathrm{~Hz}$ in $\mathbf{1 c})$.

In the ${ }^{13} \mathrm{C}\left\{{ }^{1} \mathrm{H}\right\}$ NMR spectrum, two doublets are observed for the carbonyl carbon atoms (1a: $220.4 \mathrm{ppm},{ }^{2} J_{\mathrm{CP}}=7.3 \mathrm{~Hz}$, $216.1 \mathrm{ppm},{ }^{2} J_{\mathrm{CP}}=13.7 \mathrm{~Hz} ; 1$ b: $208.8 \mathrm{ppm},{ }^{2} J_{\mathrm{CP}}=23.7 \mathrm{~Hz}$,

Table 1 Selected spectroscopic data for $\mathrm{FcPH}_{2}, 1 \mathrm{a}-\mathrm{c}, 2 \mathrm{a}-\mathrm{c}, 3 \mathrm{a}-\mathrm{c}, 4 \mathrm{a}, \mathrm{b}$ and 5

\begin{tabular}{lcll}
\hline Compound & $\delta^{31} \mathrm{P}(\mathrm{ppm})$ & ${ }^{1} J_{\mathrm{PH}}(\mathrm{Hz})$ & $\nu(\mathrm{CO})\left(\mathrm{cm}^{-1}\right)$ \\
\hline FcPH & -144.2 & 203.6 & - \\
$\mathbf{1 a}$ & -47.5 & 333.9 & $2066,1946,1931,1917$ \\
$\mathbf{1 b}$ & -81.5 & 328.0 & $2074,1950,1933,1921$ \\
$\mathbf{1 c}$ & -101.8 & 341.5 & $2073,1935,1916,1898$ \\
$\mathbf{2 a}$ & -36.3 & 333.1 & $2018,1922,1901,1870$ \\
$\mathbf{2 b}$ & -72.4 & 326.4 & $2024,1901,1879$ \\
$\mathbf{2 c}$ & -94.2 & 328.0 & $2025,1922,1898,1865$ \\
3a & -25.9 & 306.0 & 1922,1837 \\
3b & -63.8 & 307.0 & 1932,1842 \\
$\mathbf{3 c}$ & -82.3 & 315.0 & 1938,1840 \\
$\mathbf{4 a}$ & -45.4 & 345.1 & $2073,1980,1916$ \\
$\mathbf{4 b}$ & -42.6 & 343.0 & $2071,1978,1914,1738$ \\
$\mathbf{5}$ & -74.4 & - & -
\end{tabular}


$205.0 \mathrm{ppm},{ }^{2} J_{\mathrm{CP}}=9.2 \mathrm{~Hz}$; 1c: $198.1 \mathrm{ppm},{ }^{2} J_{\mathrm{CP}}=22.2 \mathrm{~Hz}$, $195.9 \mathrm{ppm},{ }^{2} J_{\mathrm{CP}}=7.1 \mathrm{~Hz}$ ). The doublet with the larger coupling constant is assigned to the single trans carbonyl group, since ${ }^{31} \mathrm{P}-{ }^{13} \mathrm{C}$ coupling through multiple bonds is usually greatest when the bonds are linear. ${ }^{23}$

The same trends as seen for $\mathbf{1 a - c}$ are also observed for $\mathbf{2 a - c}$ in the ${ }^{1} \mathrm{H},{ }^{13} \mathrm{C}\left\{{ }^{1} \mathrm{H}\right\},{ }^{31} \mathrm{P}\left\{{ }^{1} \mathrm{H}\right\}$ and ${ }^{31} \mathrm{P}$ NMR spectra, but the spectra exhibit a higher spin system due to coupling with the second magnetically inequivalent phosphorus atom (the ${ }^{1} \mathrm{H}$ and ${ }^{31} \mathrm{P}$ NMR spectra of $\mathbf{2 a}$ (experimental and simulated) are shown in Fig. S1 and S2, ESI $\dagger$ ). The signals in the ${ }^{31} \mathrm{P}$ NMR spectra of 2a-c show downfield shifts of roughly 10 ppm compared to 1a-c (Table 1). The only significant change in the ${ }^{1} \mathrm{H}$ NMR spectra of $\mathbf{2 a - c}$ compared to $\mathbf{1 a - c}$ is the increased complexity of the signal of the hydrogen atoms attached to the phosphorus atoms due to the apparent $\mathrm{AA}^{\prime} \mathrm{X}_{2} \mathrm{X}_{2}^{\prime}(\mathbf{2 a}, \mathbf{b})$ or $\mathrm{AA}^{\prime}$ $\mathrm{MX}_{2} \mathrm{X}_{2}^{\prime}$ (2c) spin system. These signals are observed at $5.23 \mathrm{in}$ 2a, 5.22 in $\mathbf{2 b}$ and $5.53 \mathrm{ppm}$ in 2c. Accordingly, the ${ }^{13} \mathrm{C}\left\{{ }^{1} \mathrm{H}\right\}$ NMR spectra of $\mathbf{2 a - c}$ show increased complexity due to the second phosphorus atom, but the same downfield shift trend is observed from chromium to tungsten. The greatest change is seen in the carbonyl carbon signals, which become more deshielded (downfield shifts of 3.9 to $6.2 \mathrm{ppm}$ ). This deshielding of the carbonyl carbon atoms is accompanied by a decrease in $\nu(\mathrm{CO})$ of the $\mathrm{A}_{1}$ carbonyl mode (2018-2025 $\mathrm{cm}^{-1}$, Table 1) in the IR spectra of $2 \mathrm{a}-\mathrm{c}$ by about $50 \mathrm{~cm}^{-1}$ due to increased backbonding between the $d_{M}$ and $\pi^{*}$ orbitals of the M-CO bond, which is due to the presence of the second $\mathrm{FcPH}_{2}$ ligand. ${ }^{24}$

Introduction of a third ferrocenylphosphine ligand further increases the complexity of the ${ }^{1} \mathrm{H},{ }^{13} \mathrm{C}\left\{{ }^{1} \mathrm{H}\right\},{ }^{31} \mathrm{P}\left\{{ }^{1} \mathrm{H}\right\}$ and ${ }^{31} \mathrm{P}$ NMR spectra $\left(\mathrm{AA}^{\prime} \mathrm{A}^{\prime \prime} \mathrm{X}_{2} \mathrm{X}_{2} \mathrm{X}^{\prime \prime}{ }_{2}(\mathbf{3 a}, \mathrm{b})\right.$ or $\mathrm{AA}^{\prime} \mathrm{A}^{\prime \prime} \mathrm{MX}_{2} \mathrm{X}_{2}{ }_{2} \mathrm{X}_{2}{ }_{2}(\mathbf{3 c})$ spin system; the ${ }^{1} \mathrm{H}$ and ${ }^{31} \mathrm{P}$ NMR spectra of $\mathbf{3 a}$ (experimental and simulated) are shown in Fig. S3 and S4, ESI $\dagger$ ). However, the trends seen in the spectra of $\mathbf{2 a - c}$ are also observed in those of 3a-c. $\delta\left({ }^{31} \mathrm{P}\right)$ of $3 \mathbf{a}-\mathbf{c}$ is shifted further downfield by about $10 \mathrm{ppm}$ (Table 1). This suggests increasing deshielding of the phosphine with increased substitution. This same deshielding trend is seen between cis- $\left[\mathrm{M}(\mathrm{CO})_{4}\left(\mathrm{PH}_{2} \mathrm{Ph}\right)_{2}\right]$ and fac$\left[\mathrm{M}(\mathrm{CO})_{3}\left(\mathrm{PH}_{2} \mathrm{Ph}\right)_{3}\right]\left(\mathrm{M}=\mathrm{Mo}, \mathrm{W} ; \mathrm{M}=\mathrm{Mo}, \delta\left({ }^{31} \mathrm{P}\right)\right.$ is -60.5 and $-53.5 \mathrm{ppm} ; \mathrm{M}=\mathrm{W}, \delta\left({ }^{31} \mathrm{P}\right)$ is -80.9 and $\left.-72.0 \mathrm{ppm}\right) .{ }^{25}$ In addition, the ${ }^{31} \mathrm{P}\left\{{ }^{1} \mathrm{H}\right\}$ NMR spectra of the tungsten complexes (1c, $2 \mathrm{c}$ and 3c) show ${ }^{31} \mathrm{P}-{ }^{183} \mathrm{~W}$ coupling which decreases from $221.0 \mathrm{~Hz}$ in $\left[\mathrm{W}(\mathrm{CO})_{5}\left(\mathrm{PH}_{2} \mathrm{Fc}\right)\right](1 \mathrm{c})$ to $209.0 \mathrm{~Hz}$ in $\mathrm{fac}$ $\left[\mathrm{W}(\mathrm{CO})_{3}\left(\mathrm{PH}_{2} \mathrm{Fc}\right)_{3}\right](3 \mathrm{c})$. Coupling to the two NMR active $(I=5 / 2)$ molybdenum isotopes, ${ }^{95} \mathrm{Mo}$ and ${ }^{97} \mathrm{Mo}$, is only observed for fac- $\left[\mathrm{Mo}(\mathrm{CO})_{3}\left(\mathrm{PH}_{2} \mathrm{Fc}\right)_{3}\right](3 \mathbf{b})$. In the ${ }^{13} \mathrm{C}\left\{{ }^{1} \mathrm{H}\right\}$ NMR spectra of $\mathbf{3 a - c}$ the signals of the carbonyl carbon atoms are also shifted by about 4 ppm compared to $\mathbf{2 a - c}$.

\section{Molecular structures}

Single-crystal X-ray structure determinations were carried out for 1a, 1c, 2a-c, 3a and 3b. Complexes 1a and 1c are isostructural, as are complexes $\mathbf{2 a - c}$ and complexes $\mathbf{3 a}, \mathbf{b}$. Therefore, only one representative structure is shown here in each case (1a (Fig. 1, Table 2), 2a (Fig. 2, Table 3), and 3a (Fig. 3, Table 4). Furthermore, in $\mathbf{2 a - c}$ two symmetry-independent

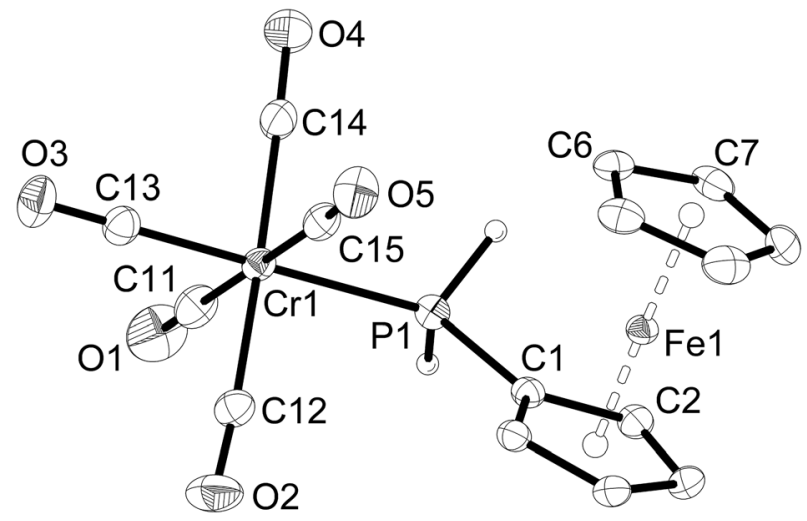

Fig. 1 Molecular structure of $\left[\mathrm{Cr}(\mathrm{CO})_{5}\left(\mathrm{PH}_{2} \mathrm{Fc}\right)\right]$ (1a). The hydrogen atoms of the ferrocenyl moiety are omitted for clarity. Ellipsoids drawn at $50 \%$ probability.

Table 2 Selected bond lengths (pm) and bond angles $\left(^{\circ}\right)$ for $1 \mathrm{a}$ and $1 \mathrm{c}$

\begin{tabular}{lll}
\hline Compound & $\mathbf{1 a}(\mathbf{M}=\mathrm{Cr})$ & $\mathbf{1 c}(\mathrm{M}=\mathrm{W})$ \\
\hline $\mathrm{M}(1)-\mathrm{P}(1)$ & $236.30(3)$ & $251.12(8)$ \\
$\mathrm{M}(1)-\mathrm{C}(13)$ & $186.4(1)$ & $201.0(3)$ \\
$\mathrm{M}(1)-\mathrm{C}(14)$ & $189.3(1)$ & $204.3(3)$ \\
$\mathrm{M}(1)-\mathrm{C}(15)$ & $189.7(1)$ & $203.5(3)$ \\
$\mathrm{M}(1)-\mathrm{C}(11)$ & $189.7(1)$ & $204.3(3)$ \\
$\mathrm{M}(1)-\mathrm{C}(12)$ & $190.4(1)$ & $205.1(3)$ \\
$\mathrm{P}(1)-\mathrm{C}(1)$ & $179.9(1)$ & $180.0(3)$ \\
$\mathrm{O}(1)-\mathrm{C}(11)$ & $113.8(2)$ & $113.6(4)$ \\
$\mathrm{O}(2)-\mathrm{C}(12)$ & $113.8(2)$ & $113.4(4)$ \\
$\mathrm{O}(3)-\mathrm{C}(13)$ & $114.8(2)$ & $114.3(4)$ \\
$\mathrm{O}(4)-\mathrm{C}(14)$ & $113.9(2)$ & $113.6(4)$ \\
$\mathrm{O}(5)-\mathrm{C}(15)$ & $113.9(2)$ & $113.9(4)$ \\
$\mathrm{C}(13)-\mathrm{M}(1)-\mathrm{P}(1)$ & $179.06(4)$ & $179.5(1)$ \\
$\mathrm{C}(14)-\mathrm{M}(1)-\mathrm{P}(1)$ & $90.09(4)$ & $90.6(1)$ \\
$\mathrm{C}(15)-\mathrm{M}(1)-\mathrm{P}(1)$ & $90.80(4)$ & $90.30(9)$ \\
$\mathrm{C}(11)-\mathrm{M}(1)-\mathrm{P}(1)$ & $89.17(4)$ & $88.9(1)$ \\
$\mathrm{C}(12)-\mathrm{M}(1)-\mathrm{P}(1)$ & $91.83(4)$ & $92.13(9)$ \\
$\mathrm{C}(1)-\mathrm{P}(1)-\mathrm{M}(1)$ & $122.49(4)$ & $121.69(9)$
\end{tabular}

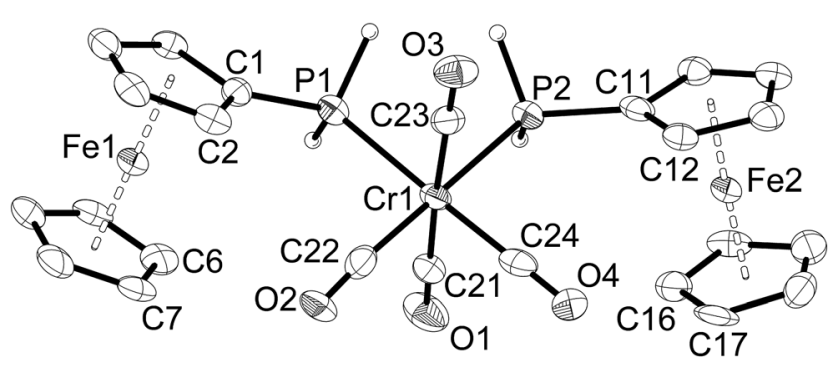

Fig. 2 Molecular structure of cis- $\left[\mathrm{Cr}(\mathrm{CO})_{4}\left(\mathrm{PH}_{2} \mathrm{Fc}\right)_{2}\right](2 \mathrm{a})$. The hydrogen atoms of the ferrocenyl moieties are omitted for clarity. Ellipsoids drawn at $50 \%$ probability. Only one of the symmetry-independent molecules is shown.

molecules are present in the asymmetric unit. As these molecules have very similar structures, only one of the two molecules is shown and discussed. Complexes $\mathbf{3} \mathbf{a}$ and $\mathbf{3} \mathbf{b}$ crystallise 
Table 3 Selected bond lengths $(\mathrm{pm})$ and bond angles $\left(^{\circ}\right)$ for $2 \mathrm{a}-2 \mathrm{c}$ Values of the second symmetry-independent molecule are given in parentheses []

\begin{tabular}{|c|c|c|c|}
\hline Compound & $2 \mathbf{a}(\mathrm{M}=\mathrm{Cr})$ & $2 \mathbf{b}(\mathrm{M}=\mathrm{Mo})$ & $2 \mathrm{c}(\mathrm{M}=\mathrm{W})^{a}$ \\
\hline $\mathrm{M}(1)-\mathrm{P}(1)$ & $234.4(3)$ & 250.4(1) & $249.3(2)$ \\
\hline$[\mathrm{M}(2)-\mathrm{P}(3)]$ & {$[234.8(3)]$} & {$[250.3(1)]$} & [249.6(3)] \\
\hline $\mathrm{M}(1)-\mathrm{P}(2)$ & $235.0(3)$ & $250.2(1)$ & $249.1(2)$ \\
\hline$[\mathrm{M}(2)-\mathrm{P}(4)]$ & {$[234.4(3)]$} & [250.3(1)] & {$[249.2(2)]$} \\
\hline$M(1)-C(24)$ & $185(1)$ & $198.1(6)$ & $197(1)$ \\
\hline$[\mathrm{M}(2)-\mathrm{C}(48)]$ & {$[182.7(9)]$} & {$[198.1(6)]$} & [197(1)] \\
\hline $\mathrm{M}(1)-\mathrm{C}(22)$ & $187(1)$ & $198.8(6)$ & 199(1) \\
\hline$[\mathrm{M}(2)-\mathrm{C}(46)]$ & {$[185(1)]$} & {$[199.5(5)]$} & {$[198(1)]$} \\
\hline $\mathrm{M}(1)-\mathrm{C}(21)$ & $187(1)$ & $204.0(6)$ & $204(1)$ \\
\hline$[\mathrm{M}(2)-\mathrm{C}(47)]$ & [188(1)] & {$[203.5(5)]$} & [204(1)] \\
\hline $\mathrm{M}(1)-\mathrm{C}(23)$ & $189(1)$ & $201.9(5)$ & $198(1)$ \\
\hline$[\mathrm{M}(2)-\mathrm{C}(45)]$ & {$[188.9(9)]$} & [204.1(6)] & [201(1)] \\
\hline $\mathrm{P}(1)-\mathrm{C}(1)$ & $180(1)$ & $180.3(5)$ & $182(1)$ \\
\hline$[\mathrm{P}(3)-\mathrm{C}(25)]$ & {$[181(1)]$} & {$[180.5(5)]$} & {$[178.5(9)]$} \\
\hline$P(2)-C(11)$ & $180(1)$ & $179.7(5)$ & $180(1)$ \\
\hline$[\mathrm{P}(4)-\mathrm{C}(35)]$ & [181(1)] & {$[181.3(5)]$} & {$[180(1)]$} \\
\hline $\mathrm{C}(24)-\mathrm{M}(1)-\mathrm{P}(1)$ & $178.4(3)$ & $176.9(2)$ & $176.9(3)$ \\
\hline$[\mathrm{C}(48)-\mathrm{M}(2)-\mathrm{P}(3)]$ & {$[178.5(3)]$} & {$[178.5(2)]$} & {$[178.2(3)]$} \\
\hline $\mathrm{C}(22)-\mathrm{M}(1)-\mathrm{P}(1)$ & $93.7(3)$ & $94.0(2)$ & $93.9(3)$ \\
\hline$[\mathrm{C}(46)-\mathrm{M}(2)-\mathrm{P}(3)]$ & {$[92.8(3)]$} & {$[93.3(1)]$} & {$[93.2(3)]$} \\
\hline $\mathrm{C}(21)-\mathrm{M}(1)-\mathrm{P}(1)$ & $93.1(3)$ & $93.6(2)$ & $93.3(3)$ \\
\hline$[\mathrm{C}(47)-\mathrm{M}(2)-\mathrm{P}(3)]$ & {$[87.1(3)]$} & {$[86.5(1)]$} & {$[85.8(3)]$} \\
\hline $\mathrm{C}(23)-\mathrm{M}(1)-\mathrm{P}(1)$ & $87.0(3)$ & $86.7(1)$ & $86.4(3)$ \\
\hline$[\mathrm{C}(45)-\mathrm{M}(2)-\mathrm{P}(3)]$ & {$[88.8(3)]$} & [89.1(2)] & {$[88.9(3)]$} \\
\hline $\mathrm{C}(24)-\mathrm{M}(1)-\mathrm{P}(2)$ & $93.1(3)$ & $92.8(2)$ & $92.8(3)$ \\
\hline$[\mathrm{C}(48)-\mathrm{M}(2)-\mathrm{P}(4)]$ & {$[94.1(3)]$} & {$[94.2(2)]$} & {$[94.0(3)]$} \\
\hline $\mathrm{C}(22)-\mathrm{M}(1)-\mathrm{P}(2)$ & $178.8(3)$ & $178.6(2)$ & $178.2(3)$ \\
\hline$[\mathrm{C}(46)-\mathrm{M}(2)-\mathrm{P}(4)]$ & {$[178.4(3)]$} & {$[177.6(1)]$} & {$[177.5(3)]$} \\
\hline $\mathrm{C}(21)-\mathrm{M}(1)-\mathrm{P}(2)$ & $89.3(3)$ & $89.0(2)$ & $88.7(3)$ \\
\hline$[\mathrm{C}(47)-\mathrm{M}(2)-\mathrm{P}(4)]$ & {$[87.3(3)]$} & {$[86.6(2)]$} & {$[86.5(3)]$} \\
\hline $\mathrm{C}(23)-\mathrm{M}(1)-\mathrm{P}(2)$ & $86.7(3)$ & $86.7(2)$ & $86.6(3)$ \\
\hline$[\mathrm{C}(45)-\mathrm{M}(2)-\mathrm{P}(4)]$ & {$[91.5(3)]$} & {$[93.7(2)]$} & {$[93.0(3)]$} \\
\hline $\mathrm{P}(1)-\mathrm{M}(1)-\mathrm{P}(2)$ & $85.7(1)$ & $84.85(4)$ & $84.52(8)$ \\
\hline$[\mathrm{P}(4)-\mathrm{M}(2)-\mathrm{P}(3)]$ & {$[85.7(9)]$} & {$[84.88(4)]$} & {$[84.69(8)]$} \\
\hline $\mathrm{C}(1)-\mathrm{P}(1)-\mathrm{M}(1)$ & $122.8(3)$ & $122.6(2)$ & $122.6(3)$ \\
\hline$[\mathrm{C}(25)-\mathrm{P}(3)-\mathrm{M}(2)]$ & {$[124.5(3)]$} & {$[124.2(2)]$} & {$[123.9(3)]$} \\
\hline $\mathrm{C}(11)-\mathrm{P}(2)-\mathrm{M}(1)$ & $124.8(3)$ & $124.5(2)$ & $123.9(3)$ \\
\hline$[\mathrm{C}(35)-\mathrm{P}(4)-\mathrm{M}(2)]$ & {$[124.2(3)]$} & {$[122.9(2)]$} & {$[122.6(3)]$} \\
\hline
\end{tabular}

${ }^{a}$ As a result of the extremely small and moderately diffracting crystal (small needle), the carbon atoms of $2 \mathrm{c}$ were refined isotropically.

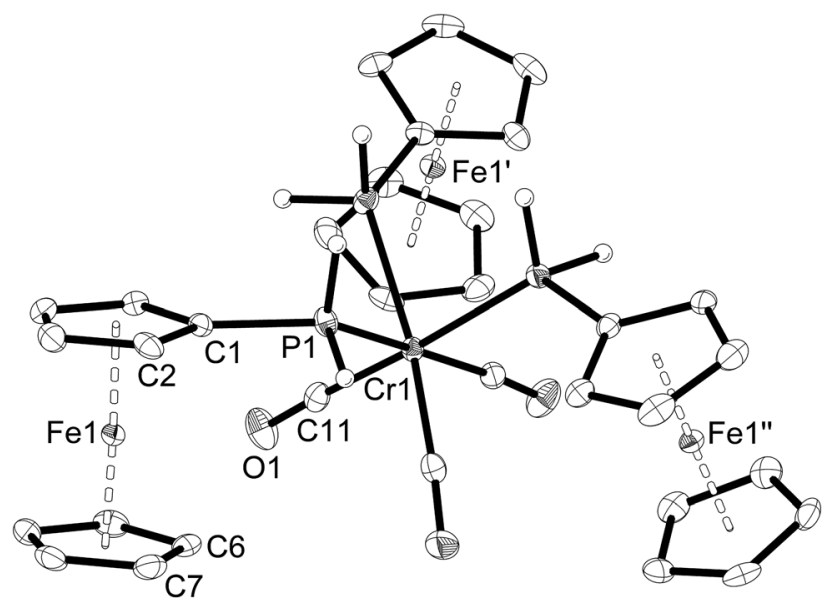

Fig. 3 Molecular structure of $\mathrm{fac}-\left[\mathrm{Cr}(\mathrm{CO})_{3}\left(\mathrm{PH}_{2} \mathrm{Fc}\right)_{3}\right]$ (3a). The hydrogen atoms of the ferrocenyl moieties are omitted for clarity. Ellipsoids drawn at $50 \%$ probability. Symmetry operators: Fe1': $1-y, 2+x-y, z ; F e 1^{\prime \prime}:-1$ $-x+y, 1-x, z$.
Table 4 Selected bond lengths ( $\mathrm{pm}$ ) and bond angles $\left(^{\circ}\right)$ for $3 a$ and $3 b$

\begin{tabular}{lll}
\hline Compound & 3a $(\mathbf{M}=\mathrm{Cr})$ & $\mathbf{3 b}(\mathbf{M}=\mathbf{M o})$ \\
\hline $\mathrm{M}(1)-\mathrm{P}(1)$ & $235.15(6)$ & $250.57(7)$ \\
$\mathrm{P}(1)-\mathrm{C}(1)$ & $180.5(2)$ & $180.6(2)$ \\
$\mathrm{M}(1)-\mathrm{C}(11)$ & $184.9(2)$ & $198.0(3)$ \\
$\mathrm{C}(11)-\mathrm{M}(1)-\mathrm{C}(11)^{\prime}$ & $88.0(1)$ & $87.8(1)$ \\
$\mathrm{C}(11)-\mathrm{M}(1)-\mathrm{P}(1)$ & $172.70(7)$ & $173.64(7)$ \\
$\mathrm{C}(11)^{\prime}-\mathrm{M}(1)-\mathrm{P}(1)$ & $87.55(7)$ & $88.50(7)$ \\
$\mathrm{C}(11)^{\prime \prime}-\mathrm{M}(1)-\mathrm{P}(1)$ & $97.62(7)$ & $97.22(7)$ \\
$\mathrm{P}(1)-\mathrm{M}(1)-\mathrm{P}(1)^{\prime}$ & $87.26(3)$ & $86.83(2)$ \\
$\mathrm{C}(1)-\mathrm{P}(1)-\mathrm{M}(1)$ & $125.87(7)$ & $125.34(8)$
\end{tabular}

in the trigonal space group $R 3$ with three molecules in the unit cell. The chirality arises from the lack of rotoinversion symmetry elements in the molecule. The molecules are located on a crystallographic $C_{3}$ axis.

All complexes retain the octahedral geometry of the parent metal carbonyl complexes with bond angles at the metal centre ranging from $88.0(1)$ to $92.13(9)^{\circ}$ in $\mathbf{1 a}$ and 1c, but become more distorted with bond angles ranging from 84.5(1)-94.3(4) ${ }^{\circ}$ in $\mathbf{2 a - c}$. The most acute angle in $\mathbf{2 a - c}$ is the $\mathrm{P}-\mathrm{M}-\mathrm{P}$ angle, which suggests that there is less steric hindrance between the ferrocenylphosphine ligands than between the carbonyl ligands. The $\mathrm{P}-\mathrm{Cr}-\mathrm{P}$ bond angles increase from $85.7(1)^{\circ}$ in $2 \mathbf{a}$ to $87.26(3)^{\circ}$ in $3 \mathbf{a}$. The $\mathrm{Cr}-\mathrm{P}-\mathrm{C}$ bond angles also become more obtuse, increasing from $122.49(4)^{\circ}$ in $1 \mathrm{a}$ to $123.8(3)^{\circ}$ (average) in $2 \mathrm{a}$ and finally to $125.87(7)^{\circ}$ in 3a. Likewise, the $\mathrm{P}-\mathrm{Mo}-\mathrm{P}\left(86.83(2)^{\circ}(3 \mathbf{b}), 84.85(4)^{\circ}(2 \mathbf{b})\right)$ and $\mathrm{Mo}-\mathrm{P}-\mathrm{C}$ $\left(125.34(8)^{\circ}(3 \mathbf{b}), 123.5(2)^{\circ}(\mathbf{2 b})\right)$ (average) bond angles in $\mathbf{3 b}$ increase compared to $\mathbf{2 b}$. The $\mathrm{P}-\mathrm{Mo}-\mathrm{P}$ bond angle in cis$\left[\mathrm{Mo}(\mathrm{CO})_{4}\left(\mathrm{PH}_{2} \mathrm{Ph}\right)_{2}\right]^{25}$ is $87.9(1)^{\circ}$, as opposed to the more acute angle of $84.85(4)^{\circ}$ in $2 \mathbf{b}$. The $\mathrm{M}-\mathrm{P}-\mathrm{C}_{\mathrm{Fc}}$ bond angles are large and very similar for all complexes (122.49(4) and 121.69(9) ${ }^{\circ}$ in 1a and 1c and slightly larger in $2 a-c\left(122.6(3)\right.$ to $\left.124.8(3)^{\circ}\right)$ and 3a,c $\left(125.87(7)\right.$ and $\left.125.34(8)^{\circ}\right)$. In comparison, the Mo-P-C bond angles in cis-[Mo(CO $\left.)_{4}\left(\mathrm{PH}_{2} \mathrm{Ph}\right)_{2}\right]$ are more acute $\left(120.6(1)^{\circ}\right)$ compared to $\mathbf{2 b}$. The $\mathrm{P}-\mathrm{C}_{\mathrm{Fc}}$ bond lengths of $\mathbf{1 a}-\mathbf{c}$ and $\mathbf{2 a - c}$ are also very similar (ca. $180 \mathrm{pm})$ as are the ferrocenyl moieties in these complexes.

However, the bond lengths around the metal atom differ greatly between the complexes, as expected from the larger differences in atomic radii. For example, the $\mathrm{Cr}-\mathrm{P}$ bond length of $1 \mathrm{a}$ is $236.30(3) \mathrm{pm}$, and the $\mathrm{W}-\mathrm{P}$ bond length of $1 \mathrm{c}$ is $251.12(8)$ pm. The $\mathrm{Cr}-\mathrm{P}$ and $\mathrm{W}-\mathrm{P}$ bond lengths of $\mathbf{2 a}$ and $2 \mathbf{c}$ are shorter than those of $\mathbf{1 a}$ and 1c. This is again due the second $\mathrm{FcPH}_{2}$ ligand. The $\mathrm{Cr}-\mathrm{P}$ bond lengths remain relatively constant at 236.30(3) pm in 1a, 234.4(3) and 235.0(3) pm in 2a and 235.15(6) pm in 3a. The Mo-P bond in $\mathbf{3 b}$ increases insignificantly to $250.57(7) \mathrm{pm}$ from $250.3(1) \mathrm{pm}$ in 2b. Likewise, the Mo-P bond lengths of cis- $\left[\mathrm{Mo}(\mathrm{CO})_{4}\left(\mathrm{PH}_{2} \mathrm{Ph}\right)_{2}\right]$ and fac$\left[\mathrm{Mo}(\mathrm{CO})_{3}\left(\mathrm{PH}_{2} \mathrm{Ph}\right)_{3}\right]$ do not change at $250.8(3)$ and $249.8(3) \mathrm{pm}$, respectively. ${ }^{25}$

The average $\mathrm{Cr}-\mathrm{C}$ bond length of $1 \mathrm{a}$ is 189.1(1) pm with the shortest bond (186.4(1) pm) trans to phosphorus. Bond lengths of $1 \mathrm{c}$ follow the same trend but are longer (average $\mathrm{W}-\mathrm{C}$ bond 
length is 203.6(3) pm with the shortest bond (201.0(3) pm) trans to phosphorus). The bond lengths around the $\mathrm{Cr}$ and $\mathrm{W}$ atoms of $2 \mathrm{a}$ and $2 \mathrm{c}$ are shorter than those of $1 \mathrm{a}$ and $1 \mathrm{c}$ (2a: average Cr-C 186.9(1) pm; 2c: W-C average 199.7(1) pm). The same trend is observed in $\mathbf{2 b}$ which has an average Mo-C bond length of 200.7(6) pm (Mo-C 202.0(1) pm in $\left.\left[\mathrm{M}(\mathrm{CO})_{4}\left(\mathrm{PH}_{2} \mathrm{Ph}\right)_{2}\right]^{25}\right)$ and for 3a,b (3a: Cr-C 184.9(2) pm; 3b: Mo-C 198.0(3) pm). This shortening can be attributed to increased back-bonding between the metal centre and carbonyl ligands and is supported by a decrease in the $A_{1}$ mode of the $\mathrm{CO}$ stretching vibration (Table 1). This correlation was also observed for the phenylphosphine complexes $\left[\mathrm{M}(\mathrm{CO})_{4}\left(\mathrm{PH}_{2} \mathrm{Ph}\right)_{2}\right]$ and $\left[\mathrm{M}(\mathrm{CO})_{3}\left(\mathrm{PH}_{2} \mathrm{Ph}\right)_{3}\right](\mathrm{M}=\mathrm{Cr}, \mathrm{Mo}, \mathrm{W}) .{ }^{25}$

\section{Hydrophosphination}

The addition of $\mathrm{P}-\mathrm{H}$ bonds to $\mathrm{C}-\mathrm{C}$ double or triple bonds (hydrophosphination reaction) is a very versatile way of synthesising new phosphines. ${ }^{3,26}$ After seminal work on catalytic hydrophosphination, ${ }^{26 g, h}$ renewed activity in this area was observed recently. ${ }^{26 i-k}$ Therefore, the ability of the coordinated ferrocenylphosphine to undergo hydrophosphination reactions was tested by screening $1 \mathrm{c}$ with a number of alkene substrates. $\mathrm{KO} t \mathrm{Bu}(10 \mathrm{~mol} \%$ ) was used to catalyse the hydrophosphination reactions, and dry THF was employed as the reaction medium to allow for sufficient solubility of all reaction components. The general procedure involved mixing 1c with $\mathrm{KO} t \mathrm{Bu}$ in THF followed by addition of one equivalent of one of the alkene substrates, all of which are liquids, after which the mixture was heated to reflux for several hours. Subsequent analysis of the reaction mixture by ${ }^{31} \mathrm{P}\left\{{ }^{1} \mathrm{H}\right\}$ NMR spectroscopy showed that alkenes bearing an electron-donating group (EDG), that is, styrene and cyclopentene, did not undergo hydrophosphination even when refluxing was continued for $24 \mathrm{~h}$. However, alkenes with an electron-withdrawing group (EWG) did undergo hydrophosphination, and the stronger the EWG effect the faster the reaction. Thus, hydrophosphination of acrylonitrile, which bears a strong EWG, was complete after $5 \mathrm{~h}$, while that of methyl acrylate, containing a weak EWG, took 20 h. The products $\left[\mathrm{W}(\mathrm{CO})_{5}\left\{\mathrm{PH}(\mathrm{Fc})\left(\mathrm{CH}_{2} \mathrm{CH}_{2} \mathrm{CN}\right)\right\}\right](\mathbf{4 a})$ and $\left[\mathrm{W}(\mathrm{CO})_{5}\left\{\mathrm{PH}(\mathrm{Fc})\left(\mathrm{CH}_{2} \mathrm{CH}_{2} \mathrm{C}(\mathrm{O}) \mathrm{OMe}\right)\right\}\right]$ (4b) were purified by column chromatography (they are eluted considerably more slowly than 1c) and fully characterised (Scheme 4).

The ${ }^{1} \mathrm{H},{ }^{31} \mathrm{P}\left\{{ }^{1} \mathrm{H}\right\}$ and ${ }^{31} \mathrm{P}$ NMR spectra confirm the antiMarkovnikov addition of the $\mathrm{P}-\mathrm{H}$ bond across the $\mathrm{C}-\mathrm{C}$ double

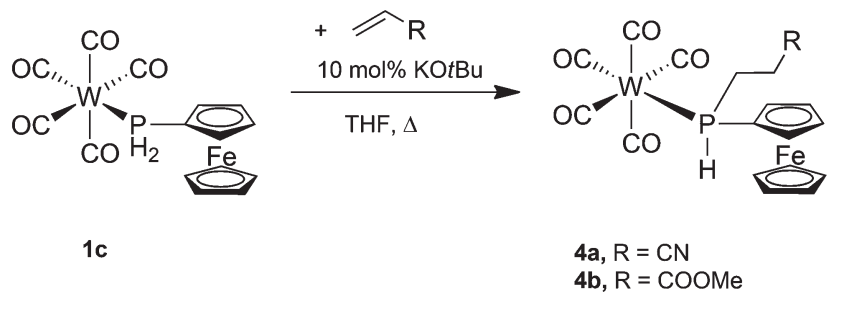

Scheme 4 Synthesis of $\left[\mathrm{W}(\mathrm{CO})_{5}\left\{\mathrm{PH}(\mathrm{Fc})\left(\mathrm{CH}_{2} \mathrm{CH}_{2} \mathrm{CN}\right)\right\}\right] \quad$ (4a) and $\left[\mathrm{W}(\mathrm{CO})_{5}\left\{\mathrm{PH}(\mathrm{Fc})\left(\mathrm{CH}_{2} \mathrm{CH}_{2} \mathrm{C}(\mathrm{O}) \mathrm{OMe}\right)\right\}\right](4 \mathrm{~b})$. bond of the alkene substrate. In the ${ }^{1} \mathrm{H}$ NMR spectrum, the signal of the $\mathrm{P}-\mathrm{H}$ protons of $\mathbf{4 a}$ and $\mathbf{4 b}$ is shifted downfield (5.87 or $5.76 \mathrm{ppm}$, respectively) compared to $1 \mathrm{c}$ (5.65 ppm) with a large ${ }^{31} \mathrm{P}-{ }^{1} \mathrm{H}$ coupling of $344 \mathrm{~Hz}$, a slight increase from $342 \mathrm{~Hz}$ in 1c, but appears as a doublet of triplets due to the ${ }^{3} J_{\mathrm{HH}}$ coupling of 4 or $5.4 \mathrm{~Hz}$ with the two methylene protons of the new cyanoethyl or methoxycarbonylethyl substituent. Likewise, a doublet with a large downfield shift to $-45.4 \mathrm{ppm}$ (4a, $\left.{ }^{1} J_{\mathrm{PH}}=345 \mathrm{~Hz}\right)$ or $-42.6 \mathrm{ppm}\left(\mathbf{4 b},{ }^{1} J_{\mathrm{PH}}=343 \mathrm{~Hz}\right)$ from $-101.8 \mathrm{ppm}$ in $1 \mathrm{c}$ is observed in the ${ }^{31} \mathrm{P}$ NMR spectrum. The IR spectra of $\mathbf{4 a}, \mathbf{b}$ show some similarity to that of $\mathbf{1 c}$. The carbonyl stretching frequencies are unchanged at 2073 and $2071 \mathrm{~cm}^{-1}$, respectively. The carbonyl stretching band of the carboxylate moiety of $\mathbf{4 b}$ was observed at $1738 \mathrm{~cm}^{-1}$, but no nitrile stretching band was observed for $\mathbf{4 a}$.

The distorted octahedral environment $\left(87.8(1)^{\circ}\right.$ to $\left.94.2(1)^{\circ}\right)$ and the bond lengths around the tungsten atom in $\mathbf{4 a}$ (Fig. 4) change only slightly compared to 1c (W-P 252.0(8) vs. 251.1(8) $\mathrm{pm}$ in 1c). The average $\mathrm{W}-\mathrm{C}$ bond length is 202.4(4) pm ( $c f$. 203.6(3) pm in 1c). The shortest $\mathrm{W}-\mathrm{C}$ bond $(197.9(4) \mathrm{pm})$ is again that trans to phosphorus, which is $3.1 \mathrm{pm}$ shorter than that in 1c. These very small changes in bond lengths indicate that there is no significant change in the coordination properties, which would otherwise be expected when moving from a primary to secondary phosphine. The phosphorus atom exhibits a distorted tetrahedral environment with large $\mathrm{W}-\mathrm{P}-\mathrm{C}_{\mathrm{Fc}}$ and $\mathrm{W}-\mathrm{P}-\mathrm{C}_{\mathrm{Et}}$ bond angles $\left(121.7(1)^{\circ}\right.$ and $110.7(1)^{\circ}$, respectively) and a small $\mathrm{C}_{\mathrm{Fc}}-\mathrm{P}-\mathrm{C}_{\mathrm{Et}}$ bond angle (104.0(2) $\left.)^{\circ}\right)$.

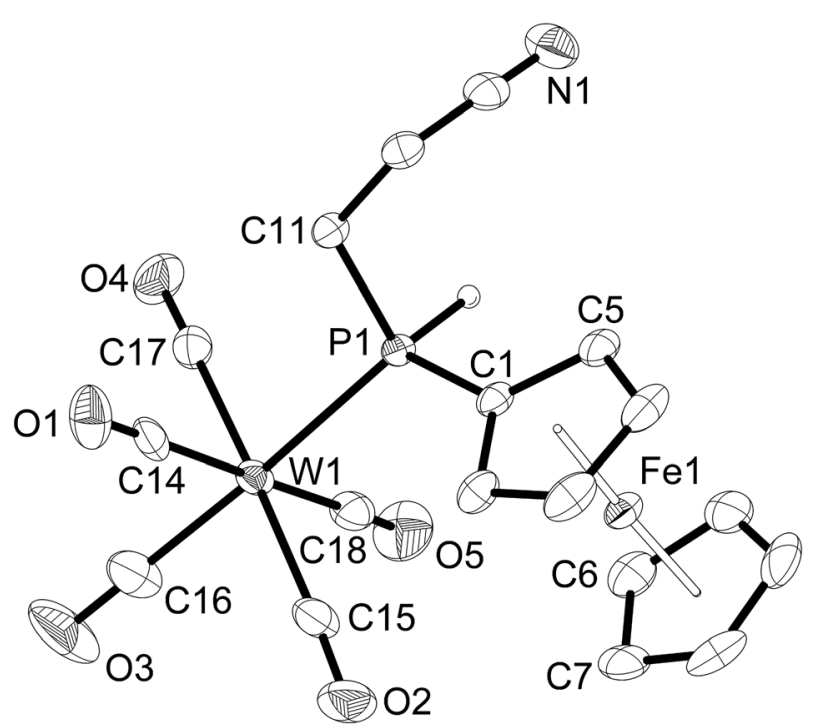

Fig. 4 Molecular structure of $\left[\mathrm{W}(\mathrm{CO})_{5}\left\{\mathrm{PH}(\mathrm{Fc})\left(\mathrm{CH}_{2} \mathrm{CH}_{2} \mathrm{CN}\right)\right\}\right]$ (4a). Hydrogen atoms other than $\mathrm{P}-\mathrm{H}$ are omitted for clarity. Ellipsoids drawn at $50 \%$ probability. Selected bond lengths $(\mathrm{pm})$ and bond angles $\left({ }^{\circ}\right)$ : $W(1)-C(16)$ 197.9(4), W(1)-C(18) 202.1(5), W(1)-C(15) 203.7(4), W(1)-C(14) 203.8(5), $W(1)-C(17) 204.5(4), W(1)-P(1) 252.04(8), P(1)-C(1)$ 178.4(3), $P(1)-C(11)$ 183.2(3), $C(16)-W(1)-P(1)$ 175.8(2), $C(18)-W(1)-P(1)$ 93.2(1), $C(15)-W(1)-P(1)$ 94.2(1), C(14)-W(1)-P(1) 87.8(1), C(17)-W(1)-P(1) 90.6(1), $C(1)-P(1)-C(11)$ 104.0(2), $C(1)-P(1)-W(1)$ 121.7(1), C(11)-P(1)-W(1) 110.7(1), $C(12)-C(11)-P(1)$ 118.3(2). 

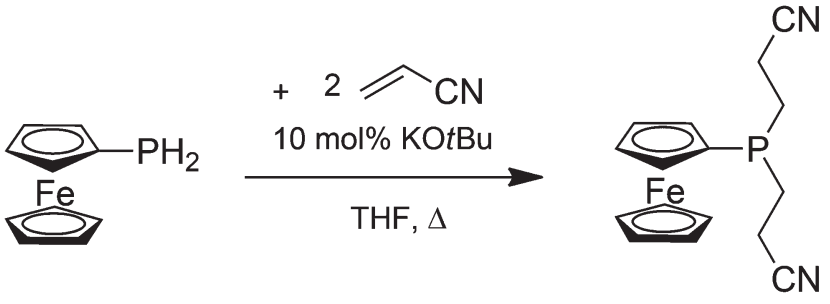

5

The findings presented above show that $\mathrm{FcPH}_{2}$ is a versatile ligand that behaves and interacts much like the far more difficult to handle $\mathrm{PhPH}_{2}$, and it also contains a useful redoxactive ferrocenyl moiety.

\section{Experimental}

\section{General methods}

Preparation of all compounds was carried out under an $\mathrm{N}_{2}$ atmosphere using standard vacuum-line and Schlenk techniques. All reactions were performed at ambient temperature and pressure unless otherwise stated. Where necessary, solvents were degassed using the standard freeze-pump-thaw method. ${ }^{29}$ The drying and distillation of solvents was conducted according to literature methods ${ }^{29}$ or solvents were dried with an MB SPS-800 Solvent Purification System. $\left[\mathrm{M}(\mathrm{CO})_{5}(\mathrm{thf})\right](\mathrm{M}=\mathrm{Cr}, \mathrm{Mo}, \mathrm{W}),{ }^{21}\left[\mathrm{M}(\mathrm{CO})_{4}(\mathrm{~L})\right](\mathrm{M}=\mathrm{Cr}, \mathrm{Mo}, \mathrm{L}=$ nbd; $\mathrm{M}=\mathrm{W}, \mathrm{L}=$ tmpa) (nbd $=2,5$-norbornadiene; tmpa = $N, N, N^{\prime}, N^{\prime}$-tetramethyl-1,3-propanediamine), ${ }^{22} \quad\left[\mathrm{M}(\mathrm{CO})_{3}(\mathrm{~L})_{3}\right]$ $(\mathrm{M}=\mathrm{Mo}, \mathrm{Cr}, \mathrm{L}=\mathrm{MeCN} ; \mathrm{M}=\mathrm{W}, \mathrm{L}=\mathrm{EtCN}),{ }^{21}$ and $\mathrm{FcPH}_{2}{ }^{3}$ were prepared according to literature methods. $\mathrm{Cr}(\mathrm{CO})_{6}$ (Roth), $\mathrm{Mo}(\mathrm{CO})_{6}$ and $\mathrm{W}(\mathrm{CO})_{6}$ (Acros) were used as supplied without further purification. Silica gel 60A (Acros) was used as the stationary phase for column chromatography. Mass spectra were obtained in ESI mode with a BRUKER Daltonics FT-ICR-MS spectrometer (Type APEX II, 7 Tesla). Elemental analysis was performed with a Heraeus VARIO EL Analyser. IR spectra $\left(4000-400 \mathrm{~cm}^{-1}\right)$ were recorded as Nujol mulls with a PerkinElmer Spectrum 2000 FT-IR spectrometer. ${ }^{1} \mathrm{H},{ }^{13} \mathrm{C}\left\{{ }^{1} \mathrm{H}\right\},{ }^{31} \mathrm{P}\left\{{ }^{1} \mathrm{H}\right\}$ and ${ }^{31} \mathrm{P}$ NMR spectra were recorded with a Bruker AVANCE DRX $400 \mathrm{MHz}$ instrument at $25{ }^{\circ} \mathrm{C}$. Chemical shifts $\delta$ of ${ }^{1} \mathrm{H},{ }^{13} \mathrm{C},{ }^{31} \mathrm{P}$ are reported in parts per million (ppm) at 400.12, 100.63 and $162.02 \mathrm{MHz}$, respectively. ${ }^{1} \mathrm{H}$ NMR spectra were referenced to TMS $(0.00 \mathrm{ppm})$ or the protic impurity solvent signals in the solvent $\mathrm{CDCl}_{3}(7.26 \mathrm{ppm}) .{ }^{13} \mathrm{C}$ NMR spectra were referenced to the solvent signal, $\mathrm{CDCl}_{3}$ (77.16 ppm). ${ }^{13} \mathrm{C}\left\{{ }^{1} \mathrm{H}\right\}$ and ${ }^{31} \mathrm{P}\left\{{ }^{1} \mathrm{H}\right\}$ experiments were referenced to TMS on the $\Xi$ scale. ${ }^{30}{ }^{31} \mathrm{P}$ NMR experiments were referenced to $85 \% \mathrm{H}_{3} \mathrm{PO}_{4}$ as external standard. Coupling constants of higher spin systems were determined by using the NMR software MestReNova 8 (Mestrelab Research). ${ }^{31}$

\section{Synthesis and characterisation}

$\mathbf{F e}\left(\boldsymbol{\eta}^{5}-\mathbf{C}_{5} \mathbf{H}_{4} \mathbf{P H}_{2}\right)\left(\eta^{5}-\mathbf{C}_{5} \mathbf{H}_{5}\right)\left(\mathbf{F c P H} \mathbf{H}_{2}\right)$. This is a modification of the method reported previously. ${ }^{12}$ A solution of $\mathrm{FcP}(\mathrm{O})(\mathrm{OEt})_{2}$ $(5.0 \mathrm{~g}, 15.5 \mathrm{mmol})$ in diethyl ether $(c a .10 \mathrm{~mL})$ was added to $\mathrm{LiAlH}_{4}(0.59 \mathrm{~g}, 15.5 \mathrm{mmol})$ in diethyl ether $(c a .20 \mathrm{~mL})$ with stirring at $c a .-70^{\circ} \mathrm{C}$. This mixture was warmed to room temperature and left to stir overnight $(14-20 \mathrm{~h})$. Unconsumed $\mathrm{LiAlH}_{4}$ was carefully hydrolysed with distilled water while the mixture was cooled over ice. The orange organic phase was separated and dried over anhydrous $\mathrm{MgSO}_{4}$. After reducing the volume to $c a .2-3 \mathrm{~mL}$ the crude product was purified by column chromatography on silica gel with $\mathrm{CH}_{2} \mathrm{Cl}_{2}$ as eluent. 
The resulting viscous orange oil was still contaminated with ferrocene, which was removed by sublimation $\left(36{ }^{\circ} \mathrm{C}, 10^{-3}\right.$ mbar) over several hours. Additional purification can be achieved by sublimation of the product, $\mathrm{FcPH}_{2}$, at $30^{\circ} \mathrm{C}$ under high vacuum $\left(10^{-6} \mathrm{mbar}\right)$. Yield $=3.22 \mathrm{~g}, 55 \%$. $\mathrm{FcPH}_{2}$ has already been described in the literature. However, the NMR data are presented here for easy reference. ${ }^{1} \mathrm{H}$ NMR $\left(\mathrm{CDCl}_{3}\right)$ : $\delta=3.81\left(\mathrm{~d}, 2 \mathrm{H},{ }^{1} \mathrm{~J}_{\mathrm{HP}}=203.6 \mathrm{~Hz}, \mathrm{PH}_{2}\right), 4.16\left(\mathrm{~s}, 5 \mathrm{H}, \mathrm{C}_{5} H_{5}\right), 4.25$ $\left(\mathrm{s}, 2 \mathrm{H}, \mathrm{C}_{5} H_{4}\right), 4.27\left(\mathrm{~s}, 2 \mathrm{H}, \mathrm{C}_{5} H_{4}\right) ;{ }^{13} \mathrm{C}\left\{{ }^{1} \mathrm{H}\right\} \mathrm{NMR}\left(\mathrm{CDCl}_{3}\right): \delta=$ $64.1\left(\mathrm{~d},{ }^{1} J_{\mathrm{CP}}=5.0 \mathrm{~Hz}\right.$, ipso-C in $\left.C_{5} \mathrm{H}_{4}\right), 69.3\left(\mathrm{~s}, C_{5} \mathrm{H}_{5}\right), 70.7$ $\left(\mathrm{d},{ }^{3} J_{\mathrm{CP}}=4.0 \mathrm{~Hz}, m-\mathrm{C}\right.$ in $\left.C_{5} \mathrm{H}_{4}\right), 75.7\left(\mathrm{~d},{ }^{2} J_{\mathrm{CP}}=13.8 \mathrm{~Hz}, o-\mathrm{C}\right.$ in $\left.C_{5} \mathrm{H}_{4}\right) ;{ }^{31} \mathrm{P} \mathrm{NMR}\left(\mathrm{CDCl}_{3}\right): \delta=-144.2\left(\mathrm{t},{ }^{1} J_{\mathrm{PH}}=203.6 \mathrm{~Hz}, \mathrm{PH}_{2}\right)$.

$\left[\mathbf{M}(\mathrm{CO})_{5}\left(\mathbf{P H}_{2} \mathrm{Fc}\right)\right](\mathbf{1 a}, \mathbf{M}=\mathbf{C r} ; \mathbf{1 b}, \mathbf{M}=\mathbf{M o} ; \mathbf{1 c}, \mathbf{M}=\mathrm{W}) . \mathrm{A}$ solution of $\mathrm{M}(\mathrm{CO})_{6}$ in $\mathrm{THF}(\mathrm{ca} .50 \mathrm{~mL})$ was irradiated with a $\mathrm{Hg}$ vapour lamp for $3 \mathrm{~h}$ at room temperature to generate $\left[\mathrm{M}(\mathrm{CO})_{5}(\mathrm{thf})\right](\mathrm{M}=\mathrm{Cr}, \mathrm{Mo}, \mathrm{W})$. This solution was then added immediately to an equimolar amount of $\mathrm{FcPH}_{2}$ in THF (ca. $10 \mathrm{~mL}$ ) and the mixture was stirred overnight at room temperature. An orange residue containing the product was obtained after all solvent and volatiles were evaporated under reduced pressure. This residue was dissolved in a minimal volume of $\mathrm{CH}_{2} \mathrm{Cl}_{2}$ (ca. $2 \mathrm{~mL}$ ) and passed through a silica gel column with $\mathrm{CH}_{2} \mathrm{Cl}_{2} / n$-hexane $(30: 70)$ as eluent. The orange band corresponding to the product was collected and the solvent evaporated under reduced pressure to obtain $\left[\mathrm{M}(\mathrm{CO})_{5}\left(\mathrm{PH}_{2} \mathrm{Fc}\right)\right]$ as an orange powder of high purity. Any remaining $\mathrm{FcPH}_{2}$ and/or $\mathrm{M}(\mathrm{CO})_{6}$ in the product was removed by sublimation under high vacuum $\left(10^{-3} \mathrm{mbar}\right)$. Yields: 1a $30 \%$, 1b $44 \%$, 1c $52 \%$.

1a: ${ }^{1} \mathrm{H}$ NMR $\left(\mathrm{CDCl}_{3}\right): \delta=4.16\left(\mathrm{~s}, 5 \mathrm{H}, \mathrm{Fe}-\mathrm{C}_{5} H_{5}\right), 4.35(\mathrm{~s}, 4 \mathrm{H}$, $\left.\mathrm{Fe}-\mathrm{C}_{5} H_{4}\right), 5.27\left(\mathrm{~d},{ }^{1} J_{\mathrm{HP}}=333.9 \mathrm{~Hz}, 2 \mathrm{H}, \mathrm{P} H_{2}\right) ;{ }^{13} \mathrm{C}\left\{{ }^{1} \mathrm{H}\right\} \mathrm{NMR}$ $\left(\mathrm{CDCl}_{3}\right): \delta=64.5\left(\mathrm{~d},{ }^{1} J_{\mathrm{CP}}=45.7 \mathrm{~Hz}\right.$, ipso-C in $\left.C_{5} \mathrm{H}_{4}\right), 69.8$ $\left(\mathrm{s}, C_{5} \mathrm{H}_{5}\right), 71.5\left(\mathrm{~d},{ }^{3} J_{\mathrm{CP}}=7.7 \mathrm{~Hz}, m-\mathrm{C}\right.$ in $\left.C_{5} \mathrm{H}_{4}\right), 73.9\left(\mathrm{~d},{ }^{2} J_{\mathrm{CP}}=\right.$ $12.2 \mathrm{~Hz}, o-\mathrm{C}$ in $\left.C_{5} \mathrm{H}_{4}\right), 216.1\left(\mathrm{~d},{ }^{2} J_{\mathrm{CP}}=13.7 \mathrm{~Hz}, C \mathrm{O} e q\right), 220.4$ $\left(\mathrm{d},{ }^{2} J_{\mathrm{CP}}=7.3 \mathrm{~Hz}, C \mathrm{O} a x\right) ;{ }^{31} \mathrm{P} \mathrm{NMR}\left(\mathrm{CDCl}_{3}\right): \delta=-47.5\left(\mathrm{t},{ }^{1} J_{\mathrm{PH}}=\right.$ $333.9 \mathrm{~Hz}, \mathrm{PH}_{2}$ ); IR (Nujol, $\mathrm{cm}^{-1}$ ): 2066w (CO), 1946m (CO), $1931 \mathrm{~s}$ (CO), 1917vs (CO); MS ESI pos., $\mathrm{CH}_{2} \mathrm{Cl}_{2} / \mathrm{MeOH}$, $m / z=431.89[\mathrm{M}+\mathrm{Na}]^{+}$; elemental analysis calcd (\%) for $\mathrm{C}_{15} \mathrm{H}_{11} \mathrm{CrFeO}_{5} \mathrm{P}: \mathrm{C}$ 43.94, $\mathrm{H}$ 2.70; found: C 44.05, $\mathrm{H} 2.68$.

1b: ${ }^{1} \mathrm{H}$ NMR $\left(\mathrm{CDCl}_{3}\right): \delta=4.24\left(\mathrm{~s}, 5 \mathrm{H}, \mathrm{Fe}-\mathrm{C}_{5} H_{5}\right), 4.40(\mathrm{~m}, 2 \mathrm{H}$, $\left.\mathrm{Fe}-\mathrm{C}_{5} H_{4}\right) 4.42\left(\mathrm{~m}, 2 \mathrm{H}, \mathrm{Fe}-\mathrm{C}_{5} H_{4}\right), 5.31\left(\mathrm{~d},{ }^{1} J_{\mathrm{HP}}=328.0 \mathrm{~Hz}, 2 \mathrm{H}\right.$, $\left.\mathrm{PH}_{2}\right) ;{ }^{13} \mathrm{C}\left\{{ }^{1} \mathrm{H}\right\}$ NMR $\left(\mathrm{CDCl}_{3}\right): \delta=63.7\left(\mathrm{~d},{ }^{1} J_{\mathrm{CP}}=45.9 \mathrm{~Hz}\right.$, ipso-C in $\left.C_{5} \mathrm{H}_{4}\right), 69.9\left(\mathrm{~s}, C_{5} \mathrm{H}_{5}\right), 71.8\left(\mathrm{~d},{ }^{3} J_{\mathrm{CP}}=7.7 \mathrm{~Hz}, m-\mathrm{C}\right.$ in $\left.C_{5} \mathrm{H}_{4}\right)$, $74.7\left(\mathrm{~d},{ }^{2} J_{\mathrm{CP}}=13.2 \mathrm{~Hz}, o-\mathrm{C}\right.$ in $\left.C_{5} \mathrm{H}_{4}\right), 205.0\left(\mathrm{~d},{ }^{2} J_{\mathrm{CP}}=9.2 \mathrm{~Hz}\right.$, CO $e q$ ), $208.8\left(\mathrm{~d},{ }^{2} J_{\mathrm{CP}}=23.7 \mathrm{~Hz}, C \mathrm{O} a x\right) ;{ }^{31} \mathrm{P} \mathrm{NMR}\left(\mathrm{CDCl}_{3}\right): \delta=$ $-81.5\left(\mathrm{t},{ }^{1} J_{\mathrm{PH}}=328.0 \mathrm{~Hz}, P \mathrm{H}_{2}\right)$; IR (Nujol, $\left.\mathrm{cm}^{-1}\right)$ : $2074 \mathrm{w}(\mathrm{CO})$, 1950s (CO), 1933s (CO), 1921vs (CO); MS ESI pos., $\mathrm{CH}_{2} \mathrm{Cl}_{2}$ / $\mathrm{MeOH}, m / z=477.86[\mathrm{M}+\mathrm{Na}]^{+}$; elemental analysis calcd $(\%)$ for $\mathrm{C}_{15} \mathrm{H}_{11} \mathrm{FeMoO}_{5} \mathrm{P}$ : C 39.68, $\mathrm{H}$ 2.44; found: C 39.59, $\mathrm{H} 2.40$.

1c: ${ }^{1} \mathrm{H}$ NMR $\left(\mathrm{CDCl}_{3}\right): \delta=4.25\left(\mathrm{~s}, 5 \mathrm{H}, \mathrm{Fe}-\mathrm{C}_{5} H_{5}\right), 4.42(\mathrm{~m}, 2 \mathrm{H}$, $\left.\mathrm{Fe}-\mathrm{C}_{5} H_{4}\right), 4.46\left(\mathrm{~m}, 2 \mathrm{H}, \mathrm{Fe}-\mathrm{C}_{5} H_{4}\right), 5.65\left(\mathrm{~d},{ }^{1} J_{\mathrm{HP}}=341.5 \mathrm{~Hz}, 2 \mathrm{H}\right.$, $\left.\mathrm{PH}_{2}\right) ;{ }^{13} \mathrm{C}\left\{{ }^{1} \mathrm{H}\right\}$ NMR $\left(\mathrm{CDCl}_{3}\right): \delta=63.5\left(\mathrm{~d},{ }^{1} J_{\mathrm{CP}}=51.9 \mathrm{~Hz}\right.$, ipso-C in $\left.C_{5} \mathrm{H}_{4}\right), 70.0\left(\mathrm{~s}, C_{5} \mathrm{H}_{5}\right), 71.9\left(\mathrm{~d},{ }^{3} J_{\mathrm{CP}}=8.1 \mathrm{~Hz}, m-\mathrm{C}\right.$ in $\left.C_{5} \mathrm{H}_{4}\right)$, $74.6\left(\mathrm{~d},{ }^{2} J_{\mathrm{CP}}=13.2 \mathrm{~Hz}, o-\mathrm{C}\right.$ in $\left.C_{5} \mathrm{H}_{4}\right), 195.9\left(\mathrm{~d},{ }^{2} J_{\mathrm{CP}}=7.1 \mathrm{~Hz}\right.$, CO $e q$ ), $198.1\left(\mathrm{~d},{ }^{2} J_{\mathrm{CP}}=22.2 \mathrm{~Hz}, C \mathrm{O} a x\right) ;{ }^{31} \mathrm{P}$ NMR $\left(\mathrm{CDCl}_{3}\right): \delta=$ -101.8 (t with ${ }^{183} \mathrm{~W}$ satellites, ${ }^{1} J_{\mathrm{PH}}=341.5 \mathrm{~Hz},{ }^{1} J_{\mathrm{PW}}=221.0 \mathrm{~Hz}$, $\mathrm{PH}_{2}$ ); IR (Nujol, $\mathrm{cm}^{-1}$ ): 2073w (CO), 1935vs (CO), 1916vs (CO), 1898s (CO); MS ESI pos., $\mathrm{CH}_{2} \mathrm{Cl}_{2} / \mathrm{MeOH}, \quad m / z=563.90$ $[\mathrm{M}+\mathrm{Na}]^{+}$; elemental analysis calcd $(\%)$ for $\mathrm{C}_{15} \mathrm{H}_{11} \mathrm{FeO}_{5} \mathrm{PW}$ : C 33.25; H 2.05; found: C 33.30; H 1.99.

cis $-\left[\mathrm{M}(\mathrm{CO})_{4}\left(\mathrm{PH}_{2} \mathrm{Fc}\right)_{2}\right](2 \mathrm{a}, \mathbf{M}=\mathbf{C r} ; 2 \mathrm{~b}, \mathbf{M}=\mathrm{Mo} ; 2 \mathrm{c}, \mathbf{M}=\mathrm{W}) . \mathrm{A}$ solution containing two equivalents of $\mathrm{FcPH}_{2}$ in toluene $(5.0 \mathrm{~mL})$ was added to a solution of $\left[\mathrm{M}(\mathrm{CO})_{4}(\mathrm{~L})\right](\mathrm{M}=\mathrm{Cr}$ or $\mathrm{Mo}$, $\mathrm{L}=\mathrm{nbd} ; \mathrm{M}=\mathrm{W}, \mathrm{L}=\mathrm{tmpa})$ in toluene $(c a .10 \mathrm{~mL})$ at room temperature. The mixture was stirred overnight at room temperature or, in the case of $2 \mathbf{c}$, heated to $60{ }^{\circ} \mathrm{C}$. The solvent and volatiles were then removed under high vacuum $\left(10^{-3} \mathrm{mbar}\right)$. The remaining orange residue was dissolved in a minimal volume of $\mathrm{CH}_{2} \mathrm{Cl}_{2}(\mathrm{ca} .2 \mathrm{~mL})$ and passed through a silica gel column with $\mathrm{CH}_{2} \mathrm{Cl}_{2} / n$-hexane $(1: 1)$ as eluent. The orange band corresponding to the product was collected and the solvent evaporated under reduced pressure until pale orange crystals of pure cis- $\left[\mathrm{M}(\mathrm{CO})_{4}\left(\mathrm{PH}_{2} \mathrm{Fc}\right)_{2}\right]$ formed. The crystals were isolated by filtration, washed with $n$-hexane $(3 \times$ $10 \mathrm{~mL}$ ) and dried under vacuum. Yields: 2a 59\%, 2b 58\%, 2c $69 \%$.

2a: ${ }^{1} \mathrm{H} \mathrm{NMR}\left(\mathrm{CDCl}_{3}\right): \delta=4.22\left(\mathrm{~s}, 10 \mathrm{H}, \mathrm{Fe}-\mathrm{C}_{5} \mathrm{H}_{5}\right), 4.38(\mathrm{br} \mathrm{s}$, $\left.4 \mathrm{H}, \mathrm{Fe}-\mathrm{C}_{5} H_{4}\right), 4.41$ (br s, $\left.4 \mathrm{H}, \mathrm{Fe}-\mathrm{C}_{5} H_{4}\right), 5.23\left(\mathrm{~m},{ }^{1} J_{\mathrm{HP}}=\right.$ $333.1 \mathrm{~Hz},{ }^{3} J_{\mathrm{HP}}=13.0 \mathrm{~Hz}, 4 \mathrm{H}, \mathrm{PH}_{2}, \mathrm{AA}^{\prime} \mathrm{X}_{2} \mathrm{X}_{2}^{\prime}$ spin system, simulated $^{31}$ (see ESI $\left.\left.\dagger\right)\right) ;{ }^{13} \mathrm{C}\left\{{ }^{1} \mathrm{H}\right\} \operatorname{NMR}\left(\mathrm{CDCl}_{3}\right): \delta=65.9\left(\mathrm{t},{ }^{1} J_{\mathrm{CP}}=\right.$ $49.5 \mathrm{~Hz},{ }^{3} J_{\mathrm{CP}}=25.3 \mathrm{~Hz}$, ipso-C in $\left.C_{5} \mathrm{H}_{4}\right), 69.9\left(\mathrm{~s}, C_{5} \mathrm{H}_{5}\right), 71.3$ $\left(\mathrm{t},{ }^{3} J_{\mathrm{CP}}=7.1 \mathrm{~Hz},{ }^{5} J_{\mathrm{CP}}=3.3 \mathrm{~Hz}, m-\mathrm{C}\right.$ in $\left.C_{5} \mathrm{H}_{4}\right), 74.0\left(\mathrm{t},{ }^{2} J_{\mathrm{CP}}=\right.$ $11.1 \mathrm{~Hz},{ }^{4} J_{\mathrm{CP}}=5.6 \mathrm{~Hz}, o-\mathrm{C}$ in $\left.C_{5} \mathrm{H}_{4}\right), 220.1\left(\mathrm{t},{ }^{2} J_{\mathrm{CP}}=14.4 \mathrm{~Hz}\right.$, CO cis), 226.0 (d, ${ }^{2} J_{\mathrm{CP}}=9.3 \mathrm{~Hz}$, CO trans); ${ }^{31} \mathrm{P} \mathrm{NMR}\left(\mathrm{CDCl}_{3}\right): \delta=$ $-36.3\left(\mathrm{~m},{ }^{1} J_{\mathrm{PH}}=333.1 \mathrm{~Hz},{ }^{2} J_{\mathrm{PP}}=-29.0 \mathrm{~Hz}, P \mathrm{H}_{2}, \mathrm{AA}^{\prime} \mathrm{X}_{2} \mathrm{X}_{2}^{\prime}\right.$ spin system, simulated $^{31}$ (see ESI†)); IR (Nujol, $\mathrm{cm}^{-1}$ ): 2018w (CO), 1922s (CO), 1901s (CO), 1870vs (CO); MS ESI pos., $\mathrm{CH}_{2} \mathrm{Cl}_{2}$ / $\mathrm{MeOH}, m / z=622.9[\mathrm{M}+\mathrm{Na}]^{+}$; elemental analysis calcd (\%) for $\mathrm{C}_{24} \mathrm{H}_{22} \mathrm{CrFe}_{2} \mathrm{O}_{4} \mathrm{P}_{2}$ : C 48.04, H, 3.70; found: C 47.93, H, 3.61.

2b: ${ }^{1} \mathrm{H}$ NMR $\left(\mathrm{CDCl}_{3}\right): \delta=4.24\left(\mathrm{~s}, 10 \mathrm{H}, \mathrm{Fe}-\mathrm{C}_{5} H_{5}\right), 4.40(\mathrm{br} \mathrm{s}$, $\left.4 \mathrm{H}, \mathrm{Fe}-\mathrm{C}_{5} H_{4}\right), 4.42\left(\mathrm{br} \mathrm{s}, 4 \mathrm{H}, \mathrm{Fe}-\mathrm{C}_{5} H_{4}\right), 5.22\left(\mathrm{~m},{ }^{1} J_{\mathrm{HP}}=\right.$ $327.0 \mathrm{~Hz},{ }^{3} J_{\mathrm{HP}}=11.0 \mathrm{~Hz}, 4 \mathrm{H}, \mathrm{PH}_{2}, \mathrm{AA}^{\prime} \mathrm{X}_{2} \mathrm{X}_{2}^{\prime}$ spin system); ${ }^{13} \mathrm{C}\left\{{ }^{1} \mathrm{H}\right\} \mathrm{NMR}\left(\mathrm{CDCl}_{3}\right): \delta=64.8\left(\mathrm{t},{ }^{1} J_{\mathrm{CP}}=48.5 \mathrm{~Hz},{ }^{3} J_{\mathrm{CP}}=24.2 \mathrm{~Hz}\right.$, ipso-C in $\left.C_{5} \mathrm{H}_{4}\right), 69.9\left(\mathrm{~s}, C_{5} \mathrm{H}_{5}\right), 71.5\left(\mathrm{t},{ }^{3} J_{\mathrm{CP}}=7.1 \mathrm{~Hz},{ }^{5} J_{\mathrm{CP}}=\right.$ $3.5 \mathrm{~Hz}, m-\mathrm{C}$ in $\left.C_{5} \mathrm{H}_{4}\right), 74.7\left(\mathrm{t},{ }^{2} J_{\mathrm{CP}}=12.1 \mathrm{~Hz},{ }^{4} J_{\mathrm{CP}}=6.1 \mathrm{~Hz}, o-\mathrm{C}\right.$ in $\left.C_{5} \mathrm{H}_{4}\right), 208.1\left(\mathrm{t},{ }^{2} J_{\mathrm{CP}}=9.5 \mathrm{~Hz}, C \mathrm{O} c i s\right), 214.1\left(\mathrm{~d},{ }^{2} J_{\mathrm{CP}}=9.3 \mathrm{~Hz}\right.$, CO trans $) ;{ }^{31} \mathrm{P}$ NMR $\left(\mathrm{CDCl}_{3}\right): \delta=-72.4\left(\mathrm{~m},{ }^{1} J_{\mathrm{PH}}=326.4 \mathrm{~Hz}\right.$, ${ }^{2} J_{\mathrm{PP}}=-17.0 \mathrm{~Hz}, \mathrm{PH}_{2} \mathrm{AA}^{\prime} \mathrm{X}_{2} \mathrm{X}_{2}^{\prime}$ spin system); IR (Nujol, $\mathrm{cm}^{-1}$ ): 2024w (CO), 1901vs (CO), 1879s (CO); MS ESI pos., $\mathrm{CH}_{2} \mathrm{Cl}_{2}$ / $\mathrm{MeOH}, m / z=668.8[\mathrm{M}+\mathrm{Na}]^{+}$; elemental analysis calcd (\%) for $\mathrm{C}_{24} \mathrm{H}_{22} \mathrm{Fe}_{2} \mathrm{MoO}_{4} \mathrm{P}_{2}$ : C 44.76, $\mathrm{H}$ 3.44; found: $\mathrm{C} 44.74, \mathrm{H} 3.50$.

2c: ${ }^{1} \mathrm{H} \mathrm{NMR}\left(\mathrm{CDCl}_{3}\right): \delta=4.25\left(\mathrm{~s}, 10 \mathrm{H}, \mathrm{Fe}-\mathrm{C}_{5} \mathrm{H}_{5}\right), 4.46(\mathrm{~s}, 8 \mathrm{H}$, $\left.\mathrm{Fe}-\mathrm{C}_{5} H_{4}\right), 5.53\left(\mathrm{~m},{ }^{1} J_{\mathrm{HP}}=328.0 \mathrm{~Hz},{ }^{3} J_{\mathrm{HP}}=12.0 \mathrm{~Hz}, 4 \mathrm{H}, \mathrm{PH}_{2}\right.$, $\mathrm{AA}^{\prime} \mathrm{X}_{2} \mathrm{X}_{2}^{\prime}$ spin system); ${ }^{13} \mathrm{C}\left\{{ }^{1} \mathrm{H}\right\} \operatorname{NMR}\left(\mathrm{CDCl}_{3}\right): \delta=64.6\left(\mathrm{~m},{ }^{1} J_{\mathrm{CP}}=\right.$ $50.6 \mathrm{~Hz},{ }^{3} J_{\mathrm{CP}}=26.3 \mathrm{~Hz}$, ipso-C in $\left.C_{5} \mathrm{H}_{4}\right), 69.9\left(\mathrm{~s}, C_{5} \mathrm{H}_{5}\right), 71.6$ $\left(\mathrm{p},{ }^{3} J_{\mathrm{CP}}=8.1 \mathrm{~Hz},{ }^{5} J_{\mathrm{CP}}=4.0 \mathrm{~Hz}, m-\mathrm{C}\right.$ in $\left.C_{5} \mathrm{H}_{4}\right), 74.6\left(\mathrm{t},{ }^{2} J_{\mathrm{CP}}=\right.$ $12.1 \mathrm{~Hz},{ }^{4} J_{\mathrm{CP}}=6.1 \mathrm{~Hz}, o-\mathrm{C}$ in $\left.C_{5} \mathrm{H}_{4}\right), 200.0\left(\mathrm{t},{ }^{2} J_{\mathrm{CP}}=7.3 \mathrm{~Hz}, C \mathrm{O}\right.$ cis), 204.3 (m, CO trans); ${ }^{31} \mathrm{P} \mathrm{NMR}\left(\mathrm{CDCl}_{3}\right): \delta=-94.2\left(\mathrm{~m},{ }^{1} J_{\mathrm{PH}}=\right.$ $328.0 \mathrm{~Hz},{ }^{2} J_{\mathrm{PP}}=-11.0 \mathrm{~Hz},{ }^{1} J_{\mathrm{WP}}=214.9 \mathrm{~Hz}, P_{2} \mathrm{AA}^{\prime} \mathrm{MX}_{2} \mathrm{X}_{2}$ spin system); IR (Nujol, $\mathrm{cm}^{-1}$ ): 2025w (CO), 1922s (CO), 1898s (CO), 1865vs (CO); MS ESI pos., $\mathrm{CH}_{2} \mathrm{Cl}_{2} / \mathrm{MeOH}, \mathrm{m} / \mathrm{z}=754.9$ $[\mathrm{M}+\mathrm{Na}]^{+}$; elemental analysis calcd (\%) for $\mathrm{C}_{24} \mathrm{H}_{22} \mathrm{Fe}_{2} \mathrm{O}_{4} \mathrm{P}_{2} \mathrm{~W}$ : C 39.38, H 3.03; found: C 39.35, H 2.86 . 
fac $-\left[\mathrm{M}(\mathrm{CO})_{3}\left(\mathrm{PH}_{2} \mathrm{Fc}\right)_{3}\right](3 \mathrm{a}, \mathbf{M}=\mathrm{Cr} ; 3 \mathbf{b}, \mathbf{M}=\mathbf{M o} ; 3 \mathbf{c}, \mathbf{M}=\mathbf{W})$. A solution of three equivalents of $\mathrm{FcPH}_{2}$ in $\mathrm{CH}_{2} \mathrm{Cl}_{2}(5.0 \mathrm{~mL})$ was added to a solution of $f a c-\left[\mathrm{M}(\mathrm{CO})_{3}(\mathrm{~L})_{3}\right](\mathrm{M}=\mathrm{Mo}, \mathrm{Cr}, \mathrm{L}=\mathrm{MeCN}$; $\mathrm{M}=\mathrm{W}, \mathrm{L}=\mathrm{EtCN})$ in $\mathrm{CH}_{2} \mathrm{Cl}_{2}(c a .10 \mathrm{~mL})$ at room temperature. The mixture was stirred overnight before the solvent and volatiles were removed under high vacuum $\left(10^{-3} \mathrm{mbar}\right)$. The orange residue was dissolved in a minimal volume of $\mathrm{CH}_{2} \mathrm{Cl}_{2}(c a .2 \mathrm{~mL})$ and passed through a silica gel column, first with a $1: 1$ mixture of $\mathrm{CH}_{2} \mathrm{Cl}_{2}$ and $n$-hexane to elute any cis-[M(CO) $\left.)_{4}\left(\mathrm{PH}_{2} \mathrm{Fc}\right)_{2}\right]$, followed by a 3:1 mixture to elute the product. The orange band corresponding to the product was collected and the solvent evaporated under reduced pressure until pale orange crystals of pure $f a c-\left[\mathrm{M}(\mathrm{CO})_{3}\left(\mathrm{PH}_{2} \mathrm{Fc}\right)_{3}\right]$ formed. The crystals where isolated by filtration, washed with $n$-hexane $(3 \times 10 \mathrm{~mL})$ and dried under vacuum. Yields: $3 \mathbf{a} 43 \%, 3 \mathbf{b} 31 \%$, 3c $52 \%$.

3a: ${ }^{1} \mathrm{H}$ NMR $\left(\mathrm{CDCl}_{3}\right): \delta=4.16\left(\mathrm{~s}, 15 \mathrm{H}, \mathrm{Fe}-\mathrm{C}_{5} H_{5}\right), 4.35(\mathrm{~s}, 6 \mathrm{H}$, $\left.\mathrm{Fe}-\mathrm{C}_{5} H_{4}\right), 4.42\left(\mathrm{~s}, 6 \mathrm{H}, \mathrm{Fe}-\mathrm{C}_{5} H_{4}\right), 5.10\left(\mathrm{~m},{ }^{1} J_{\mathrm{HP}}=306.3 \mathrm{~Hz}\right.$, ${ }^{3} J_{\mathrm{HP}}=15.0 \mathrm{~Hz}, 6 \mathrm{H}, \mathrm{PH}_{2}, \mathrm{AA}^{\prime} \mathrm{A}^{\prime \prime} \mathrm{X}_{2} \mathrm{X}_{2}{ }_{2} \mathrm{X}_{2}{ }_{2}$ spin system, simulated ${ }^{31}$ (see ESI $\left.\dagger\right)$ ); ${ }^{13} \mathrm{C}\left\{{ }^{1} \mathrm{H}\right\}$ NMR $\left(\mathrm{CDCl}_{3}\right): \delta=67.1(\mathrm{~m}$, ipso-C in $\left.C_{5} \mathrm{H}_{4}\right), 69.8\left(\mathrm{~s}, C_{5} \mathrm{H}_{5}\right), 70.9\left(\mathrm{~m}, m-\mathrm{C}\right.$ in $\left.C_{5} \mathrm{H}_{4}\right), 73.9(\mathrm{~m}, o-\mathrm{C}$ in $\left.C_{5} \mathrm{H}_{4}\right), 230.3(\mathrm{~m}, \mathrm{CO}) ;{ }^{31} \mathrm{P}$ NMR $\left(\mathrm{CDCl}_{3}\right): \delta=-25.9\left(\mathrm{~m},{ }^{1} J_{\mathrm{PH}}=\right.$ $306.0 \mathrm{~Hz},{ }^{2} J_{\mathrm{PP}}=-11.0 \mathrm{~Hz}, \mathrm{PH}_{2}, \mathrm{AA}^{\prime} \mathrm{A}^{\prime \prime} \mathrm{X}_{2} \mathrm{X}_{2}^{\prime} \mathrm{X}^{\prime \prime}{ }_{2}$ spin system, simulated $^{31}$ (see ESI $\dagger$ )); IR (Nujol, $\mathrm{cm}^{-1}$ ): 1922s (CO), $1837 \mathrm{vs}$ (CO); MS ESI pos., $\mathrm{CH}_{2} \mathrm{Cl}_{2} / \mathrm{MeCN}, \mathrm{m} / \mathrm{z}=812.9$ $[\mathrm{M}+\mathrm{Na}]^{+}, \quad 789.9[\mathrm{M}]^{+}$; elemental analysis calcd (\%) for $\mathrm{C}_{33} \mathrm{H}_{33} \mathrm{CrFe}_{3} \mathrm{O}_{3} \mathrm{P}_{3}$ : C 50.17, $\mathrm{H}$ 4.21; found: C 50.02, $\mathrm{H} 4.17$.

3b: ${ }^{1} \mathrm{H}$ NMR $\left(\mathrm{CDCl}_{3}\right): \delta=4.25\left(\mathrm{~s}, 15 \mathrm{H}, \mathrm{Fe}-\mathrm{C}_{5} H_{5}\right), 4.36(\mathrm{~s}, 6 \mathrm{H}$, $\left.\mathrm{Fe}-\mathrm{C}_{5} H_{4}\right), 4.44\left(\mathrm{~s}, 6 \mathrm{H}, \mathrm{Fe}-\mathrm{C}_{5} H_{4}\right), 5.08\left(\mathrm{~m},{ }^{1} J_{\mathrm{HP}}=307.0 \mathrm{~Hz}\right.$, ${ }^{3} J_{\mathrm{HP}}=8.0 \mathrm{~Hz}, 6 \mathrm{H}, \mathrm{PH}_{2}, \mathrm{AA}^{\prime} \mathrm{A}^{\prime \prime} \mathrm{X}_{2} \mathrm{X}_{2}{ }_{2} \mathrm{X}_{2}{ }_{2}$ spin system); ${ }^{13} \mathrm{C}\left\{{ }^{1} \mathrm{H}\right\}$ NMR $\left(\mathrm{CDCl}_{3}\right): \delta=66.1\left(\mathrm{~m}\right.$, ipso-C in $\left.C_{5} \mathrm{H}_{4}\right), 69.9\left(\mathrm{~s}, C_{5} \mathrm{H}_{5}\right), 71.2$ $\left(\mathrm{m}, m-\mathrm{C}\right.$ in $\left.C_{5} \mathrm{H}_{4}\right), 74.7\left(\mathrm{~m}, o-\mathrm{C}\right.$ in $\left.C_{5} \mathrm{H}_{4}\right), 218.8(\mathrm{~m}, C \mathrm{O})$; ${ }^{31} \mathrm{P}$ NMR $\left(\mathrm{CDCl}_{3}\right): \delta=-63.8\left(\mathrm{~m},{ }^{1} J_{\mathrm{PH}}=307.0 \mathrm{~Hz},{ }^{2} J_{\mathrm{PP}}=-17 \mathrm{~Hz}\right.$, ${ }^{1} J_{95 \mathrm{MoP}}=121.5 \mathrm{~Hz},{ }^{1} J_{97 \mathrm{MoP}}=166.9 \mathrm{~Hz}, \mathrm{PH}_{2}, \mathrm{AA}^{\prime} \mathrm{A}^{\prime \prime} \mathrm{MX}_{2} \mathrm{X}_{2}{ }_{2} \mathrm{X}^{\prime \prime}{ }_{2}$ spin system); IR (Nujol, $\mathrm{cm}^{-1}$ ): 1932s (CO), 1842vs (CO); MS ESI pos., $\mathrm{CH}_{2} \mathrm{Cl}_{2} / \mathrm{MeOH}, m / z=858.8[\mathrm{M}+\mathrm{Na}]^{+}$; elemental analysis calcd (\%) for $\mathrm{C}_{33} \mathrm{H}_{33} \mathrm{Fe}_{3} \mathrm{MoO}_{3} \mathrm{P}_{3}$ : C 47.52; $\mathrm{H}$ 3.99; found: $\mathrm{C}$ 47.26, H 3.93.

3c: ${ }^{1} \mathrm{H}$ NMR $\left(\mathrm{CDCl}_{3}\right): \delta=4.25\left(\mathrm{~s}, 15 \mathrm{H}, \mathrm{Fe}-\mathrm{C}_{5} H_{5}\right), 4.38(\mathrm{~s}, 6 \mathrm{H}$, Fe- $\left.\mathrm{C}_{5} H_{4}\right), 4.45\left(\mathrm{~s}, 6 \mathrm{H}, \mathrm{Fe}-\mathrm{C}_{5} H_{4}\right), 5.41\left(\mathrm{~m},{ }^{1} J_{\mathrm{HP}}=315.0 \mathrm{~Hz}\right.$, ${ }^{3} J_{\mathrm{HP}}=9.0 \mathrm{~Hz}, 6 \mathrm{H}, \mathrm{PH}_{2}, \mathrm{AA}^{\prime} \mathrm{A}^{\prime \prime} \mathrm{MX}_{2} \mathrm{X}_{2}^{\prime} \mathrm{X}^{\prime \prime}{ }_{2}$ spin system); ${ }^{13} \mathrm{C}\left\{{ }^{1} \mathrm{H}\right\}$ $\operatorname{NMR}\left(\mathrm{CDCl}_{3}\right): \delta=65.9\left(\mathrm{~d},{ }^{1} J_{\mathrm{CP}}=57.6 \mathrm{~Hz}\right.$, ipso-C in $\left.C_{5} \mathrm{H}_{4}\right), 70.0$ (s, $\left.C_{5} \mathrm{H}_{5}\right), 71.3\left(\mathrm{~m}, m-\mathrm{C}\right.$ in $\left.C_{5} \mathrm{H}_{4}\right), 74.6\left(\mathrm{~m}, o-\mathrm{C}\right.$ in $\left.C_{5} \mathrm{H}_{4}\right), 209.9$ $(\mathrm{m}, \mathrm{CO}) ;{ }^{31} \mathrm{P} \mathrm{NMR}\left(\mathrm{CDCl}_{3}\right): \delta=-82.3\left(\mathrm{~m},{ }^{1} J_{\mathrm{PH}}=315.0 \mathrm{~Hz},{ }^{2} J_{\mathrm{PP}}=\right.$ $-9.0 \mathrm{~Hz},{ }^{1} J_{\mathrm{PW}}=209.0 \mathrm{~Hz}, \mathrm{PH}_{2}, \mathrm{AA}^{\prime} \mathrm{A}^{\prime \prime} \mathrm{MX}_{2} \mathrm{X}_{2}^{\prime} \mathrm{X}^{\prime \prime}{ }_{2}$ spin system); IR (Nujol, $\mathrm{cm}^{-1}$ ): 1938s (CO), 1840vs (CO); MS ESI pos., $\mathrm{CH}_{2} \mathrm{Cl}_{2} / \mathrm{MeOH}, m / z=944.9[\mathrm{M}+\mathrm{Na}]^{+}$; elemental analysis calcd (\%) for $\mathrm{C}_{33} \mathrm{H}_{33} \mathrm{Fe}_{3} \mathrm{O}_{3} \mathrm{P}_{3} \mathrm{~W}$ : C 42.99; $\mathrm{H}$ 3.61; found: C 42.85, H 3.63 .

$\left[\mathbf{W}(\mathrm{CO})_{5}\left\{\mathbf{P H}(\mathbf{F c})\left(\mathrm{CH}_{2} \mathrm{CH}_{2} \mathrm{CN}\right)\right\}\right](4 \mathrm{a}) .1 \mathrm{c}(0.5 \mathrm{~g}, 0.923 \mathrm{mmol})$ and $\mathrm{KOtBu}(0.001 \mathrm{~g}, 0.092 \mathrm{mmol})$ were dissolved in THF $(10 \mathrm{~mL})$. Acrylonitrile $(91 \mu \mathrm{L}, 1.38 \mathrm{mmol})$ was added via syringe. The mixture was heated to reflux for 4 hours. All volatiles were removed under reduced pressure, and the orange residue was redissolved in $\mathrm{Et}_{2} \mathrm{O}$ and washed with $\mathrm{HCl}\left(1.0 \mathrm{~mol} \mathrm{~L}^{-1}\right.$, ca. $20 \mathrm{~mL}$ ). The organic layer was separated and washed three times with distilled water and then dried over anhydrous $\mathrm{MgSO}_{4}$. After filtration, all solvent was removed under reduced pressure. The orange residue was redissolved in a minimum volume of $\mathrm{CH}_{2} \mathrm{Cl}_{2}$ and passed through a silica gel column with $\mathrm{CH}_{2} \mathrm{Cl}_{2} / n$-hexane $(70: 30)$ as eluent. The product was collected in the second orange band (the first band contained unconsumed 1c, which was pure enough to be recycled). The solvent was removed to give pure $\mathbf{4 a}$ as an orange powder. Yield: $0.40 \mathrm{~g}, 72 \%$. Crystals of $\mathbf{4 a}$ were obtained from $\mathrm{CH}_{2} \mathrm{Cl}_{2} /$ $n$-hexane.

${ }^{1} \mathrm{H}$ NMR $\left(\mathrm{CDCl}_{3}\right): \delta=2.2-2.5\left(\mathrm{~m}, 4 \mathrm{H}, \mathrm{CH}_{2} \mathrm{CH}_{2} \mathrm{CN}\right), 4.22$ (s, $\left.5 \mathrm{H}, \mathrm{Fe}-\mathrm{C}_{5} H_{5}\right), 4.32\left(\mathrm{~s}, 1 \mathrm{H}, \mathrm{Fe}-\mathrm{C}_{5} H_{4}\right), 4.35\left(\mathrm{~s}, 1 \mathrm{H}, \mathrm{Fe}-\mathrm{C}_{5} H_{4}\right)$, $4.45\left(\mathrm{~s}, 1 \mathrm{H}, \mathrm{Fe}-\mathrm{C}_{5} H_{4}\right), 4.50\left(\mathrm{~s}, 1 \mathrm{H}, \mathrm{Fe}-\mathrm{C}_{5} H_{4}\right), 5.81\left(\mathrm{dt},{ }^{1} J_{\mathrm{HP}}=\right.$ $\left.346.0 \mathrm{~Hz},{ }^{3} J_{\mathrm{HH}}=5.4 \mathrm{~Hz}, 1 \mathrm{H}, \mathrm{PH}\right) ;{ }^{13} \mathrm{C}\left\{{ }^{1} \mathrm{H}\right\}$ NMR $\left(\mathrm{CDCl}_{3}\right)$ : $\delta=15.5\left(\mathrm{CH}_{2} \mathrm{CN}\right), 28.1\left(\mathrm{~d},{ }^{1} J_{\mathrm{CP}}=26.3 \mathrm{~Hz}, \mathrm{PCH}_{2}\right) 68.8\left(\mathrm{~d},{ }^{1} J_{\mathrm{CP}}=\right.$ $48.5 \mathrm{~Hz}$, ipso-C in $\left.C_{5} \mathrm{H}_{4}\right), 69.9\left(\mathrm{~s}, C_{5} \mathrm{H}_{5}\right), 72.0\left(\mathrm{~d},{ }^{3} J_{\mathrm{CP}}=10.1 \mathrm{~Hz}\right.$, $m$-C in $\left.C_{5} \mathrm{H}_{4}\right), 75.0\left(\mathrm{~d},{ }^{2} J_{\mathrm{CP}}=21.2 \mathrm{~Hz}, o-\mathrm{C}\right.$ in $\left.C_{5} \mathrm{H}_{4}\right), 118.4$ $\left(\mathrm{s}, \mathrm{CH}_{2} \mathrm{CN}\right), 196.1\left(\mathrm{~d},{ }^{2} J_{\mathrm{CP}}=7.1 \mathrm{~Hz}, \mathrm{CO} e q\right), 197.6\left(\mathrm{~d},{ }^{2} J_{\mathrm{CP}}=23.2\right.$ $\mathrm{Hz}, \quad C O \quad a x) ;{ }^{31} \mathrm{P}$ NMR $\left(\mathrm{CDCl}_{3}\right): \delta=-45.4$ (d with ${ }^{183} \mathrm{~W}$ satellites, $\left.{ }^{1} J_{\mathrm{PH}}=345.1 \mathrm{~Hz},{ }^{1} J_{\mathrm{PW}}=235.1 \mathrm{~Hz}, P \mathrm{H}\right)$; IR (Nujol, $\mathrm{cm}^{-1}$ ): 2073w (CO), 1980m (CO), 1916vs (CO); MS ESI pos., $\mathrm{CH}_{2} \mathrm{Cl}_{2} / \mathrm{MeOH}, m / z=618.0[\mathrm{M}+\mathrm{Na}]^{+}$; elemental analysis calcd (\%) for $\mathrm{C}_{18} \mathrm{H}_{14} \mathrm{NFeO}_{5} \mathrm{PW}$ : C $36.34, \mathrm{H}$ 2.37; found: C 36.18, H 2.35.

$\left[\mathrm{W}(\mathrm{CO})_{5}\left\{\mathrm{PH}(\mathrm{Fc})\left(\mathrm{CH}_{2} \mathrm{CH}_{2} \mathrm{C}(\mathrm{O}) \mathrm{OMe}\right)\right\}\right](\mathbf{4 b})$. The same procedure was used as for 4 a. 1c $(0.134 \mathrm{~g}, 0.248 \mathrm{mmol})$ and methyl acrylate $(22 \mu \mathrm{L}, 0.248 \mathrm{mmol})$ were mixed and reflux was maintained for $8 \mathrm{~h}$. Purification involved column chromatography through silica gel with $\mathrm{CH}_{2} \mathrm{Cl}_{2}$ as eluent. The product was eluted from the column as the second band. Yield: $0.09 \mathrm{~g}, 58 \%$.

${ }^{1} \mathrm{H}$ NMR $\left(\mathrm{CDCl}_{3}\right): \delta=2.3-2.6\left(\mathrm{~m}, 4 \mathrm{H}, \mathrm{CH}_{2} \mathrm{CH}_{2} \mathrm{C}(\mathrm{O}) \mathrm{OMe}\right)$, $3.69(\mathrm{~s}, 3 \mathrm{H}, \mathrm{C}(\mathrm{O}) \mathrm{OMe}), 4.27\left(\mathrm{~s}, 5 \mathrm{H}, \mathrm{Fe}-\mathrm{C}_{5} H_{5}\right), 4.39$ (d, $J=$ $\left.13.2 \mathrm{~Hz}, 2 \mathrm{H}, \mathrm{Fe}-\mathrm{C}_{5} H_{4}\right), 4.49\left(\mathrm{~d}, J=13.2 \mathrm{~Hz}, 2 \mathrm{H}, \mathrm{Fe}-\mathrm{C}_{5} H_{4}\right), 5.76$ $\left(\mathrm{dt},{ }^{1} J_{\mathrm{HP}}=344 \mathrm{~Hz},{ }^{3} J_{\mathrm{HH}}=5.6 \mathrm{~Hz}, 1 \mathrm{H}, \mathrm{PH}\right) ;{ }^{13} \mathrm{C}\left\{{ }^{1} \mathrm{H}\right\} \mathrm{NMR}$ $\left(\mathrm{CDCl}_{3}\right): \delta=26.5\left(\mathrm{~d},{ }^{1} J_{\mathrm{CP}}=29.7 \mathrm{~Hz}, \mathrm{PCH}_{2}\right), 31.0\left(\mathrm{~s}, \mathrm{CH}_{2} \mathrm{C}(\mathrm{O})-\right.$ OMe), $52.2(\mathrm{~s}, \mathrm{OMe}), 69.8\left(\mathrm{~s}, C_{5} \mathrm{H}_{5}\right), 70.7\left(\mathrm{~d},{ }^{1} J_{\mathrm{CP}}=47.7 \mathrm{~Hz}\right.$, ipso-C in $\left.C_{5} \mathrm{H}_{4}\right), 71.6\left(\mathrm{~d},{ }^{3} J_{\mathrm{CP}}=9.1 \mathrm{~Hz}, m-\mathrm{C}\right.$ in $\left.C_{5} \mathrm{H}_{4}\right), 74.5(\mathrm{~d}$, ${ }^{2} J_{\mathrm{CP}}=19.2 \mathrm{~Hz}, o-\mathrm{C}$ in $\left.C_{5} \mathrm{H}_{4}\right), 172.4\left(\mathrm{~d},{ }^{3} J_{\mathrm{CP}}=12.1 \mathrm{~Hz}, C(\mathrm{O})\right.$ OMe), $196.5\left(\mathrm{~d},{ }^{2} J_{\mathrm{CP}}=7.1 \mathrm{~Hz}, C \mathrm{CO} e q\right), 198.3\left(\mathrm{~d},{ }^{2} J_{\mathrm{CP}}=21.1 \mathrm{~Hz}\right.$, CO $a x) ;{ }^{31} \mathrm{P}$ NMR $\left(\mathrm{CDCl}_{3}\right): \delta=-42.6\left(\mathrm{~d}\right.$ with ${ }^{183} \mathrm{~W}$ satellites, ${ }^{1} J_{\mathrm{PH}}$ $\left.=343.0 \mathrm{~Hz},{ }^{1} J_{\mathrm{PW}}=231.7 \mathrm{~Hz}, P \mathrm{H}\right) ; \mathrm{IR}\left(\right.$ Nujol, $\left.\mathrm{cm}^{-1}\right): 2071 \mathrm{~m}$ (CO), 1978w (CO), 1914vs (CO), 1738m ( $\mathrm{C}=\mathrm{O})$; MS ESI neg., $\mathrm{CH}_{2} \mathrm{Cl}_{2} / \mathrm{MeOH}, m / z=626.8[\mathrm{M}-\mathrm{H}]^{-}$; elemental analysis calcd (\%) for $\mathrm{C}_{19} \mathrm{H}_{17} \mathrm{FeO}_{7} \mathrm{PW}$ : C 36.34, $\mathrm{H}$ 2.73; found: C 36.40, $\mathrm{H} 2.75$.

$\mathbf{F c P}\left(\mathrm{CH}_{2} \mathbf{C H}_{2} \mathbf{C N}\right)_{2}(5) . \quad \mathrm{FcPH}_{2}(0.5 \mathrm{~g}, 2.293 \mathrm{mmol})$ and $\mathrm{KO} t \mathrm{Bu}$ $(0.026 \mathrm{~g}, 0.229 \mathrm{mmol})$ were dissolved in THF $(10 \mathrm{~mL})$. Acrylonitrile $(0.30 \mu \mathrm{L}, 4.587 \mathrm{mmol})$ was added via syringe and the mixture was heated to reflux for $15 \mathrm{~h}$. After cooling the reaction mixture to room temperature, all volatiles were removed under reduced pressure. The orange residue was dissolved in a minimum of $\mathrm{CH}_{2} \mathrm{Cl}_{2}$ and the product isolated by column chromatography through a silica gel column under an inert atmosphere with $\mathrm{CH}_{2} \mathrm{Cl}_{2}$ as eluent. After collecting the second band (the first was pure $\mathrm{FcPH}_{2}$ ) all solvent was removed to 
leave pure $\mathrm{FcP}\left(\mathrm{CH}_{2} \mathrm{CH}_{2} \mathrm{CN}\right)_{2}$ as an oily orange solid. Yield: $0.52 \mathrm{~g}, 70 \%$.

${ }^{1} \mathrm{H}$ NMR $\left(\mathrm{CDCl}_{3}\right): \delta=1.78\left(\mathrm{~m}, 4 \mathrm{H}, \mathrm{CH}_{2} \mathrm{CH}_{2} \mathrm{CN}\right), 2.36(\mathrm{br}$, $4 \mathrm{H}, \mathrm{CH}_{2} \mathrm{CH}_{2} \mathrm{CN}$ ), 4.13 (s, $5 \mathrm{H}, \mathrm{Fe}-\mathrm{C}_{5} H_{5}$ ), 4.18 (br, $2 \mathrm{H}, \mathrm{Fe}-\mathrm{C}_{5} H_{4}$ ), $4.27\left(\mathrm{~s}, 2 \mathrm{H}, \mathrm{Fe}-\mathrm{C}_{5} H_{4}\right) ;{ }^{13} \mathrm{C}\left\{{ }^{1} \mathrm{H}\right\} \operatorname{NMR}\left(\mathrm{CDCl}_{3}\right): \delta=16.5\left(\mathrm{~d},{ }^{2} J_{\mathrm{CP}}=\right.$ $\left.7.4 \mathrm{~Hz}, \mathrm{CH}_{2} \mathrm{CN}\right), 20.5\left(\mathrm{~d},{ }^{1} J_{\mathrm{CP}}=15.1 \mathrm{~Hz}, \mathrm{PCH}_{2}\right), 68.1\left(\mathrm{~d},{ }^{1} J_{\mathrm{CP}}=\right.$ $5.1 \mathrm{~Hz}$, ipso-C in $\left.C_{5} \mathrm{H}_{4}\right), 69.0\left(\mathrm{~s}, C_{5} \mathrm{H}_{5}\right), 71.2\left(\mathrm{~s}, m-\mathrm{C}\right.$ in $\left.C_{5} \mathrm{H}_{4}\right)$, $74.6\left(\mathrm{~d},{ }^{2} J_{\mathrm{CP}}=13.4 \mathrm{~Hz}, o-\mathrm{C}\right.$ in $\left.C_{5} \mathrm{H}_{4}\right), 119.3\left(\mathrm{~s}, \mathrm{CH}_{2} \mathrm{CN}\right) ;{ }^{31} \mathrm{P}$ NMR $\left(\mathrm{CDCl}_{3}\right): \delta=-74.4$ (s); MS ESI pos., $\mathrm{CH}_{2} \mathrm{Cl}_{2} / \mathrm{MeOH}, m / z=$ $325.06[\mathrm{M}+\mathrm{H}]^{+}$.

\section{Crystal structure determinations}

The data were collected on a Gemini area detector diffractometer (Rigaku Inc.) using Mo-K $\alpha$ radiation $(\lambda=71.073 \mathrm{pm})$ and $\omega$-scan rotation. Data reduction was performed with CrysAlis-Pro $^{32}$ including the program SCALE3 ABSPACK for empirical absorption correction. The structures of 1a,c, 2a-c and $\mathbf{3 a}, \mathbf{b}$ were solved by direct methods and that of $\mathbf{4 a}$ was solved with Patterson methods with SHELXS- $97^{33}$ or SIR92. ${ }^{34}$ The refinement was performed with SHELXL-97. ${ }^{33}$ As a result of the extremely small and moderately diffracting crystal (small needle), the carbon atoms of $2 \mathrm{c}$ were refined isotropically. The non-hydrogen atoms of all other structures were refined with anisotropic thermal parameters. A difference-density Fourier map was used to locate all hydrogen atoms of $\mathbf{1 a}$ and $\mathbf{1 c}$, whereas $\mathrm{H}$ atoms of all other structures were calculated on idealised positions by using the riding model. The structures 1a and 1c are isostructural. This is also the case for the series $\mathbf{2 a - c}$ and $\mathbf{3 a}, \mathbf{b}$ (see Table S1, ESI $\dagger$ ). Structure figures were generated with ORTEP ${ }^{35}$ and DIAMOND-3. ${ }^{36}$ CCDC 1420127 (1a), 1420128 (1c), 1420129 (2a), 1420130 (2b), 1420131 (2c), 1420132 (3a), 1420133 (3b) and 1420134 (4a) contain the supplementary crystallographic data for this paper.

\section{Acknowledgements}

We gratefully acknowledge financial support from by the European Union and the Free State of Saxony (Landesinnovationspromotion for J. P. S.) and the Graduate School Leipzig School of Natural Sciences - Building with Molecules and Nanoobjects (BuildMoNa).

\section{References}

1 (a) T. B. Rauchfuss, in Homogeneous Catalysis with Metal Phosphine Complexes, ed. L. H. Pignolet, Plenum Press, New York, 1993, ch. 7; (b) Phosphorus(III) Ligands in Homogeneous Catalysis: Design and Synthesis, ed. P. C. Kamer and P. W. N. M. van Leeuven, John Wiley \& Sons Ltd., UK, 2012; (c) A. Behr and P. Neubert, Applied Homogeneous Catalysis, Wiley-VCH Verlag \& Co. KGaA, 2012.

2 D. E. C. Corbridge, Phosphorus: Chemistry, Biochemistry and Technology, CRC Press, Taylor \& Francis Group, Boca Raton, FL, 6th edn, 2013.
3 J. T. Fleming and L. J. Higham, Coord. Chem. Rev., 2015, 297-298, 127.

4 W. Henderson and S. R. Alley, J. Organomet. Chem., 2002, 656, 120.

5 N. J. Goodwin, W. Henderson, B. K. Nicholson, J. Fawcett and D. R. Russell, J. Chem. Soc., Dalton Trans., 1999, 1785.

6 N. J. Goodwin, W. Henderson and B. K. Nicholson, Chem. Commun., 1997, 31.

7 P. P. Power, R. A. Bartlett, M. M. Olmstead and G. A. Sigel, Inorg. Chem., 1987, 26, 1941.

8 P. P. Power, B. Twamley, C. Hwang and N. J. Hardman, J. Organomet. Chem., 2000, 609, 152.

9 K. V. Katti, K. R. Prabhu, N. Pillarsetty and H. Gali, J. Am. Chem. Soc., 2000, 122, 1554.

10 R. M. Hiney, L. J. Higham, H. Müller-Bunz and D. G. Gilheany, Angew. Chem., 2006, 118, 7406, (Angew. Chem. Int. Ed., 2006, 45, 7248).

11 (a) P. Štěpnička, Ferrocenes. Ligands, Materials and Biomolecules, John Wiley \& Sons Ltd., West Sussex, 2008; (b) A. Togni and T. Hayashi, Ferrocenes. Homogeneous Catalysis. Organic Synthesis. Material Science, VCH, New York, Weinheim, 1995.

12 S. Tschirschwitz, P. Lönnecke and E. Hey-Hawkins, J. Chem. Soc., Dalton Trans., 2007, 1377.

13 C. Spang, F. T. Edelmann, M. Noltemeyer and H. W. Roesky, Chem. Ber., 1989, 122, 1247.

14 R. Kalio, P. Lönnecke and E. Hey-Hawkins, J. Organomet. Chem., 2008, 693, 590.

15 R. Kalio, P. Lönnecke, A. Cinquantini, P. Zanello and E. Hey-Hawkins, Z. Anorg. Allg. Chem., 2007, 633, 2470.

16 S. I. M. Paris, F. R. Lemke, R. Sommer, P. Lönnecke and E. Hey-Hawkins, J. Organomet. Chem., 2005, 690, 1807.

17 S. I. M. Paris, J. L. Petersen, E. Hey-Hawkins and M. P. Jensen, Inorg. Chem., 2006, 45, 5561.

18 R. Sommer, P. Lönnecke, P. K. Baker and E. Hey-Hawkins, Inorg. Chem. Commun., 2002, 5, 115.

19 R. Sommer, P. Lönnecke, J. Reinhold, P. K. Baker and E. Hey-Hawkins, Organometallics, 2005, 24, 5256.

20 J. Svara, N. Weferling and T. Hofmann, Phosphorus Compounds, Organic, in Ullmann's Encyclopedia of Industrial Chemistry, John Wiley \& Sons, Inc, 2008.

21 W. A. Herrmann and A. Salzer, Synthetic Methods of Organometallic and Inorganic Chemistry, Thieme, New York, 1996, vol. 1.

22 J. C. Kotz, C. L. Nivert, J. M. Lieber and R. C. Reed, J. Organomet. Chem., 1975, 84, 255.

23 O. Kühl, Phosphorus-31 NMR Spectroscopy: A Concise Introduction for the Synthetic Organic and Organometallic Chemist, Springer, 2008.

24 R. H. Crabtree, The Organometallic Chemistry of the Transition Metals, John Wiley \& Sons, Inc., New Jersey, 5th edn, 2009.

25 T. Campbell, A. M. Gibson, R. Hart, S. D. Orchard, S. J. A. Pope and G. Reid, J. Organomet. Chem., 1999, 592, 296. 
26 (a) L. Rosenberg, ACS Catal., 2013, 3, 2845; (b) S. A. Pullarkat and P.-H. Leung, Top. Organomet. Chem., 2013, 43, 145; (c) Science of Synthesis, Stereoselective Synthesis, ed. A. L. Reznichenko and K. C. Hultzsch, J. G. De Vries, G. A. Molander and P. A. Evans, 2011, vol. 1, p. 689; (d) D. S. Glueck, Top. Organomet. Chem., 2010, 31, 65; (e) O. Delacroix and A. C. Gaumont, Curr. Org. Chem., 2005, 9, 1851; (f) W. Malisch, B. Klupfel, D. Schumacher and M. Nieger, J. Organomet. Chem., 2002, 661, 95; (g) D. K. Wicht and D. S. Glueck, in Catalytic Heterofunctionalization, ed. A. Togni and H. Grützmacher, WileyVCH Verlag GmbH, 2001, ch. 5; (h) I. P. Beletskaya, V. P. Ananikov and L. L. Khemchyan, in Phosphorus Chemistry: Catalysis and Material Science Applications, ed. M. Peruzzini and L. Gonsalvi, Springer, 2011, ch. 8, vol. 37; (i) M. B. Ghebreab, C. A. Bange and R. Waterman, J. Am. Chem. Soc., 2014, 136, 9240; (j) I. V. Basalov, V. Dorcet, G. K. Fukin, J.-F. Carpentier, Y. Sarazin and A. A. Trifonov, Chem. - Eur. J., 2015, 21, 6033; (k) C. A. Bange, M. B. Ghebreab, A. Ficks, N. T. Mucha, L. Higham and R. Waterman, Dalton Trans., 2015, DOI: 10.1039/ C5DT03544A.
27 A. J. Downard, N. J. Goodwin and W. Henderson, J. Organomet. Chem., 2003, 676, 62.

28 J. Tong, S. Liu, S. Zhang and S. Z. Li, Spectrochim. Acta, Part A, 2007, 67, 837.

29 W. L. F. Armarego and C. L. L. Chai, Purification of Laboratory Chemicals, Butterworth-Heinemann, Burlington, 5th edn, 2003.

30 R. K. Harris, E. D. Becker, S. M. Cabral De Menezes, R. Goodfellow and P. Granger, Concepts Magn. Reson., 2002, 14, 326.

31 Spectra have been simulated with the software MestReNova Version: 8.0.2-11021, 2012 Mestrelab Research S. L.

32 CrysAlis-Pro: Data collection and data reduction software package, Rigaku Inc.

33 SHELX includes SHELXS-97, SHELXL-97: G. M. Sheldrick, Acta Crystallogr., Sect. A: Fundam. Crystallogr., 2008, 64, 112.

34 A. Altomare, G. Cascarano, C. Giacovazzo and A. Guagliardi, J. Appl. Crystallogr., 1994, 27, 435.

35 ORTEP3 for Windows: L. J. Farrugia, J. Appl. Crystallogr., 1997, 30, 565.

36 K. Brandenburg, DIAMOND 3, Crystal Impact GbR, Bonn, Germany. 